PLAN OF STUDY FOR THE REGIONAL AQUIFERSYSTEM ANALYSIS OF THE APPALACHIAN

VALLEY AND RIDGE, PIEDMONT, AND BLUE

RIDGE PHYSIOGRAPHIC PROVINCES OF THE

EASTERN AND SOUTHEASTERN UNITED STATES,

WITH A DESCRIPTION OF STUDY-AREA

GEOLOGY AND HYDROGEOLOGY

By Lindsay A. Swain, Este F. Hollyday, Charles C. Daniel, III, and Otto S. Zapecza

U.S. GEOLOGICAL SURVEY

Water-Resources Investigations Report 91-4066

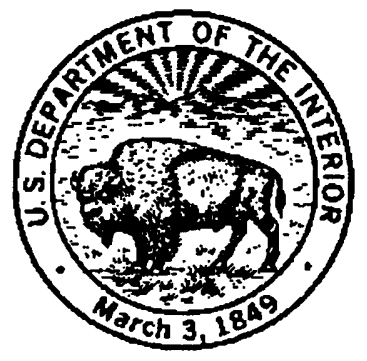




\section{U.S. DEPARTMENT OF THE INTERIOR MANUEL LUJAN, JR., Secretary \\ U.S. GEOLOGICAL SURVEY \\ Dallas L. Peck, Director}

Chief, APRASA

U.S. Geological Survey

3600 West Broad Street \#606

Richmond, VA 23230
U.S. Geological Survey

Books and Open-File Reports Section

Federal Center

Box 25425

Denver, CO 80225 


\section{CONTENTS}

Abstract 1

Introduction $\mathbf{2}$

Purpose and scope 2

Description of study area $\mathbf{3}$

Relation to other Regional Aquifer-System Analysis studies $\quad \mathbf{1 0}$

Acknowledgments

10

Geologic setting and framework 10

Valley and Ridge physiographic province 12

Piedmont and Blue Ridge physiographic provinces

Crystalline-rock regimes 13

Sedimentary-rock regimes 13

Hydrogeologic setting and framework 15

Valley and Ridge physiographic province 16

Hydrogeologic terranes and conceptual ground-water-flow systems

Carbonate rocks mantled by thick regolith

20

Carbonate and sandstone rocks mantled by thin regolith 20

Clay-rich rocks mantled by regolith

20

Deep, confined flow systems

20

Spring-basin flow systems $\mathbf{2 2}$

Ground-water quality 22

Piedmont and Blue Ridge physiographic provinces

22

Rock regimes 23

Crystalline-rock regimes 23

Sedimentary-rock regimes 25

Hydrogeologic terranes and conceptual ground-water-flow systems 25

Massive or foliated crystalline rocks mantled by thick regolith 25

Massive or foliated crystalline rocks mantled by thin regolith 26

Metamorphosed carbonate rocks 26

Sedimentary basins 26

Ground-water quality 28

Ground-water issues and problems $\quad \mathbf{2 8}$

Valley and Ridge physiographic province $\quad \mathbf{2 8}$

Piedmont and Blue Ridge physiographic provinces 31

Plan of Study $\quad 33$

Objectives $\quad 33$

Approach 33

Organization 36

Proposed reports 38

Selected references $\quad 39$ 


\section{ILLUSTRATIONS}

Figures 1-7. Maps showing:

1. The Appalachian Valleys-Piedmont Regional Aquifer-System

Analysis study area and physiographic provinces 4

2. Average annual precipitation, $1951-80$ - 6

3. Average annual runoff, 1951-80 7

4. Population distribution by county, $1985 \quad 8$

5. Total water use by county, $1985 \quad 9$

6. Location of the Appalachian Valleys-Piedmont Regional Aquifer-System Analysis study area in relation to adjacent Regional Aquifer-System Analysis studies

11

7. Location of exposed early Mesozoic basins in eastern North America

8. Diagrams showing idealized plan and sectional views of a typical local ground-water-flow system in the Valley and Ridge physiographic province

9. Block diagram showing hydrogeologic terrane of carbonate rocks mantled by thick regolith 21

10. Block diagram showing principal components of the ground-water system in the Piedmont and Blue Ridge physiographic provinces 24

11. Block diagram showing hydrogeologic terrane of massive or foliated crystalline rock mantled by thick regolith in the Piedmont or Blue Ridge physiographic provinces 27

12. Graph showing cumulative frequency distribution of specific capacity of 35 wells in the Conestoga Limestone, south-central Pennsylvania

13. Graph showing principal study tasks and tentative completion dates

\section{TABLES}

Table 1. Population in the APRASA study area, by state, $1985 \mathbf{5}$

2. Ground- and surface-water use in the study area by state and physiographic province, $1985 \quad \mathbf{1 0}$

3. Hydrologic characteristics for the hydrogeologic terranes and conceptual flow systems for the APRASA study area 


\section{CONVERSION FACTORS AND VERTICAL DATUM}

\section{Multiply}

inch (in.)

foot (ft)

mile (mi)

square mile $\left(\mathrm{mi}^{2}\right)$

cubic foot per second $\left(\mathrm{ft}^{3} / \mathrm{s}\right)$

gallons per minute ( $\mathrm{gal} / \mathrm{min})$

million gallons per day $(\mathrm{Mgal} / \mathrm{d})$
By

2.54

0.3048

1.609

2.590

0.02832

0.06309

0.04381
To Obtain

centimeter

meter

kilometer

square kilometer

cubic meter per second

litre per second

cubic metre per second

Sea level: In this report, "sea level" refers to the National Geodetic Vertical Datum of 1929 (NGDV of 1929)-a geodetic datum derived from a general adjustment of the first-order level nets of both the United States and Canada, formerly called Sea Level Datum of 1929. 


\title{
PLAN OF STUDY FOR THE REGIONAL AQUIFER- SYSTEM ANALYSIS OF THE APPALACHIAN VALLEY AND RIDGE, PIEDMONT, AND BLUE RIDGE PHYSIOGRAPHIC PROVINCES OF THE EASTERN AND SOUTHEASTERN UNITED STATES, WITH A DESCRIPTION OF STUDY AREA GEOLOGY AND HYDROGEOLOGY
}

\author{
By Lindsay A. Swain, Este F. Hollyday, Charles C. Daniel, III, \\ and Otto S. Zapecza
}

\section{ABSTRACT}

The Appalachian Valleys-Piedmont Regional Aquifer-System Analysis (APRASA) study area is in the Appalachian Highlands of the eastern United States. The study area covers about 142,000 square miles in parts of New Jersey, Delaware, Pennsylvania, Maryland, the District of Columbia, Virginia, West Virginia, Tennessee, North Carolina, South Carolina, Georgia, and Alabama. The geologic framework and hydrology of the study area are diverse and complex. During 1985, a population of about 36 million people within the study area used about 1,700 million gallons per day of ground water and 36,600 million gallons per day of surface water for all categories of water use.

Carbonate rock, sandstone, and shale within the Valley and Ridge physiographic province provided about 567 million gallons per day of ground water, or about 33 percent of the total ground water pumped in the study area during 1985. Metamorphic and igneous rocks underlie most of the Piedmont and Blue Ridge physiographic provinces, and regolith overlies these rock types. Ground water pumped from aquifers in the Piedmont physiographic province was about 986 million gallons per day, or about 58 percent of the total pumpage in the APRASA study area. Pumpage in the Blue Ridge physiographic province was about 163 million gallons per day, or about 9 percent of the total groundwater pumpage in the APRASA study area. More than 10 percent of all ground water pumped within the study area was from sedimentary basins (principally the Newark basin) within the Piedmont physiographic province.

Severe and prolonged drought, allocation of surface-water flow, and increased demands on ground-water supplies have focused the need to evaluate ground-water resources in the Valley and Ridge, Piedmont, and Blue Ridge physiographic provinces. The objectives of the APRASA study, which began in 1988, are to (1) define the hydrogeologic framework of each physiographic province; (2) identify and delineate the hydrologic processes active in each province; (3) investigate the functioning of representative ground-water-flow systems in the carbonate, sandstone, and crystalline rocks by means of computer simulation and analytical 
methods; (4) refine the present understanding of recharge and discharge processes; (5) estimate a regional water budget, including pumpage, rates of natural discharge and recharge, and changes in aquifer storage; (6) determine the importance and interrelation of surface- and ground-water-flow systems and their effects on water quality and development; and (7) develop a comprehensive ground-water data base for the region.

The approach to achieve the objectives of the APRASA will include (1) use of a Geographic Information System to define areal distribution of hydrogeologic units throughout the study area; (2) delineation of hydrogeologic terranes and conceptual flow systems representative of parts of the study area; (3) quantification of hydrologic characteristics of selected areas that are representative of the principal hydrogeologic terranes or conceptual flow systems; (4) analysis of base flow in streams in approximately 200 basins within the study area; (5) delineation of water quality by province and hydrogeologic terrane on the basis of more than 200,000 ground-water and surface-water chemical analyses for the study area; and (6) development of a ground-water data base that will be useful for future studies of the region's water resources.

\section{INTRODUCTION}

Severe and prolonged droughts during the past 20 years, combined with increased demands for freshwater supplies in the eastern part of the United States, have focused the critical need to assess the potential for development of groundand surface-water supplies. Rapid industrial growth and urban expansion have caused existing freshwater supplies to be used at or near maximum capacity.

Although large amounts of ground water and surface water are currently (1991) being withdrawn throughout the Appalachian Valley and Ridge, Piedmont, and Blue Ridge physiographic provinces, processes of recharge, discharge, storage, ground-water flow, and stream-aquifer relations within the three physiographic provinces are poorly understood. This lack of understanding is due primarily to the diverse and complex nature of the hydrologic system. This study will provide a basis for more efficient use and management of water resources within the study area than is now possible by providing data bases, a regional hydrogeologic framework, and interpretative analyses based on hydrogeologic terranes and conceptual flow systems.

This study is one of several regional investigations being made to assess the Nation's principal aquifer systems (Sun, 1986). The U.S. Geological Survey (USGS) began the Regional Aquifer-System Analysis (RASA) Program in 1978, as mandated by Congress, and was given the task of "initiating a program to identify the water resources of the major aquifer systems within the United States . . . and . . . establish the aquifer boundaries, the quantity and quality of the water within the aquifer, and the recharge characteristics of the aquifer" (Sun, 1986 , p. 2).

\section{PURPOSE AND SCOPE}

This report presents a synthesis of the existing knowledge of the ground-water resources in the Appalachian Valley and Ridge, Piedmont, and Blue Ridge physiographic provinces, and describes the plans for quantifying and improving the understanding of the groundwater resources in those three physiographic provinces.

The report describes the general geology and hydrogeology of the Appalachian ValleysPiedmont Regional Aquifer-System Analysis (APRASA) study area, which is divided into two subareas: (1) the Valley and Ridge physiographic province and (2) the Piedmont and Blue Ridge physiographic provinces. Hydrogeologic terranes and conceptual flow systems within each of the two subareas are defined and described. A table of generalized hydrologic 
characteristics for each hydrogeologic terrane or conceptual flow system allows for comparison of the hydrogeologic terranes throughout the APRASA area. The Plan of Study part of the report describes the objectives, organization, and approaches for accomplishing the objectives. This section also lists specific report products expected and work elements with tentative dates for completion.

\section{DESCRIPTION OF STUDY AREA}

The Appalachian Valleys-Piedmont Regional Aquifer-System Analysis (APRASA) study area is in the Appalachian Highlands (Fenneman, 1946) of the eastern United States. The study area covers about $142,000 \mathrm{mi}^{2}$ (square miles) in parts of New Jersey, Delaware, Pennsylvania, Maryland, the District of Columbia, Virginia, West Virginia, Tennessee, North Carolina, South Carolina, Georgia, and Alabama (fig. 1). The eastern and southern boundaries of the study area correspond to the Fall Line, beyond which sediments of Early Cretaceous and younger age form the Atlantic Coastal Plain. The western boundary corresponds to the westernmost limit of thrust faults and folds in the Valley and Ridge physiographic province; the rocks along this boundary dip steeply locally. West of the Valley and Ridge physiographic province, the Appalachian Plateaus physiographic province is underlain with gently dipping Paleozoic strata whose hydrologic characteristics differ from rocks underlying the Valley and Ridge physiographic province. The northern boundary of the study area along the Hudson River is a 1,000 -ft-thick diabase sheet called the Palisades sill; elsewhere the northern boundary is the State border between New Jersey and New York. The extreme northern end of the study area is locally mantled by deposits of glacial origin.

The Valley and Ridge physiographic province is a narrow belt averaging about $50 \mathrm{mi}$ (miles) in width which extends along the northwestern edge of the study area (fig. 1). The Valley and Ridge physiographic province extends about 1,000 mi from near Scranton, Pa.; southwest to Birmingham, Ala.; and encompasses approximately $46,000 \mathrm{mi}^{2}$. The topography of the province is irregular and consists mostly of low, undulating hills or plains with hills near the northeastern and southwestern ends that rise to low mountains in central Pennsylvania, Virginia, and West Virginia. Most of the province contains more than a dozen major northeast-trending valleys and ridges. Local relief rarely exceeds $700 \mathrm{ft}$ and land surface elevation commonly ranges from about 600 to $1,500 \mathrm{ft}$ above sea level.

The Piedmont and Blue Ridge physiographic provinces encompass approximately $96,000 \mathrm{mi}^{2}$ along the southeastern edge of the study area. These provinces extend approximately 1,000 mi from near New York City to near Montgomery, Ala. (fig. 1). In New Jersey, the Piedmont province is less than $40 \mathrm{mi}$ wide, but in North Carolina, it is about $150 \mathrm{mi}$ wide. The topography of the Piedmont physiographic province consists of low, well-rounded hills and long, northeast-trending valleys and ridges. The surfaces of many ridge tops and interstream divides are relatively flat. Recent erosion by streams has dissected the Piedmont and created a local topographic relief of 100 to $200 \mathrm{ft}$ between drainage divides and stream bottoms. Land-surface elevations in the Piedmont range from 300 to $600 \mathrm{ft}$ above sea level along the eastern border near the Fall Line to more than $1,500 \mathrm{ft}$ near the escarpment of the Blue Ridge.

The Blue Ridge physiographic province extends from a very narrow section in southern Pennsylvania to Georgia, North Carolina, and eastern Tennessee, where it is nearly $100 \mathrm{mi}$ wide. In western North Carolina, the Blue Ridge physiographic province contains the highest mountains in the eastern United States. These mountain peaks, which are as much as $6,600 \mathrm{ft}$ above sea level, form a rugged topography.

Precipitation ranges from a minimum of about $30 \mathrm{in} / \mathrm{yr}$ (inches per year) to a maximum 


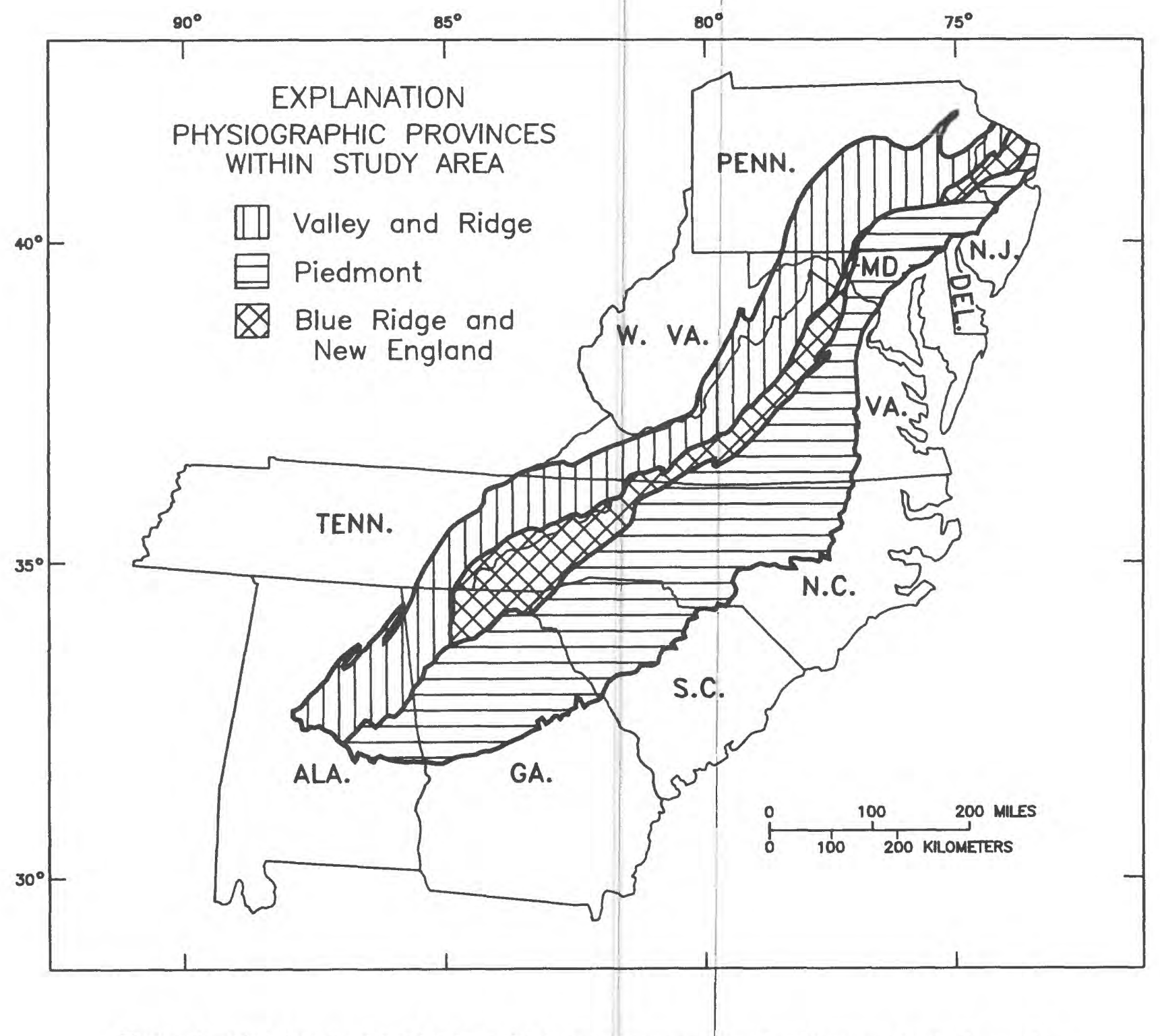

Figure 1.--The Appalachian Valleys-Piedmont Regional Aquifer-System Analysis study area and physiographic provinces. 
of nearly $80 \mathrm{in} / \mathrm{yr}$ within the study area (fig. 2). Average (1951-80) precipitation in most areas of the APRASA is 40 to $50 \mathrm{in} / \mathrm{yr}$ (U.S. Geological Survey, 1986, p. 52). The area of maximum precipitation occurs in the Blue Ridge physiographic province in western North Carolina, eastern Tennessee, and northwestern Georgia because of orographic effects of the mountain range.

Average annual runoff (1951-80) ranges from a minimum of less than $10 \mathrm{in}$. to a maximum of about 50 in. (fig. 3). Generally, average runoff is 10 to $20 \mathrm{in} / \mathrm{yr}$ in most areas (U.S. Geological Survey, 1986, p. 52; Gebert and others, 1987). Runoff generally is higher in areas of the western Piedmont and Blue Ridge physiographic provinces than it is in the rest of the study area because of higher precipitation, steep streambed gradients, shorter growing seasons, lower temperatures, and lower evapotranspiration. During periods of low flow (usually September and October) most of the sustained nonregulated streamflow is from ground-water discharge.

During 1985, more than 36 million people lived within the study area (table 1 and fig. 4). Areas of concentrated population in or adjacent to the study area are Washington, D.C.; Baltimore, Md.; Newark, N.J.; New York City, N.Y.; Richmond, Va.; Philadelphia, Pa.; Raleigh, N.C.; and Atlanta, Ga. During 1960-85, total population in each state generally has increased.

During 1985, about 1,700 Mgal/d (million gallons per day) of ground water was pumped from aquifers within the study area (table 2 and fig. 5.)

In addition, surface-water supplies provided about $36,600 \mathrm{Mgal} / \mathrm{d}$. States with the largest rates of ground-water pumpage in 1985 were Pennsylvania (495 Mgal/d), New Jersey (294 Mgal/d), Virginia (217 Mgal/d), and North Carolina (187 Mgal/d). The States with the largest rates of surface-water pumpage were Pennsylvania (8,403 Mgal/d), North Carolina
(7,170 Mgal/d), South Carolina (4,895 Mgal/d), Virginia $(4,169 \mathrm{Mgal} / \mathrm{d})$, and Tennessee $(3,510 \mathrm{Mgal} / \mathrm{d})$.

Table 1.-Population in the APRASA study area, by state, 1985

[Data from U.S. Bureau of Census]

\begin{tabular}{lr}
\hline \multicolumn{1}{c}{ State } & $\begin{array}{r}1985 \text { Population } \\
\text { (in thousands) }\end{array}$ \\
\hline Alabama & 1,689 \\
Delaware & 406 \\
District of Columbia & 626 \\
Georgia & 4,157 \\
Maryland & 3,531 \\
New Jersey & 5,072 \\
North Carol ina & 4,736 \\
Pennsylvania & 7,462 \\
South Carol ina & 1,935 \\
Tennessee & 1,723 \\
Virginia & 4,035 \\
West Virginia & 326 \\
\multicolumn{1}{c}{ Total } & \\
& 35,698 \\
\hline
\end{tabular}

Analysis of water use by physiographic province within the study area indicates the largest use was in the Piedmont province where about $986 \mathrm{Mgal} / \mathrm{d}$ (58 percent of total groundwater withdrawal) was pumped from aquifers and about $25,550 \mathrm{Mgal} / \mathrm{d}$ (70 percent of the total surface-water withdrawal) from streams. The water use in the Valley and Ridge province was $567 \mathrm{Mgal} / \mathrm{d}$ from aquifers (33 percent of the total ground-water withdrawal) and 8,132 $\mathrm{Mgal} / \mathrm{d}$ from streams (22 percent of surfacewater withdrawal). The water use in the Blue Ridge province was $163 \mathrm{Mgal} / \mathrm{d}$ from aquifers ( 9 percent of ground-water withdrawal) and 2,943 Mgal/d for streams (8 percent of the surface-water withdrawal). 


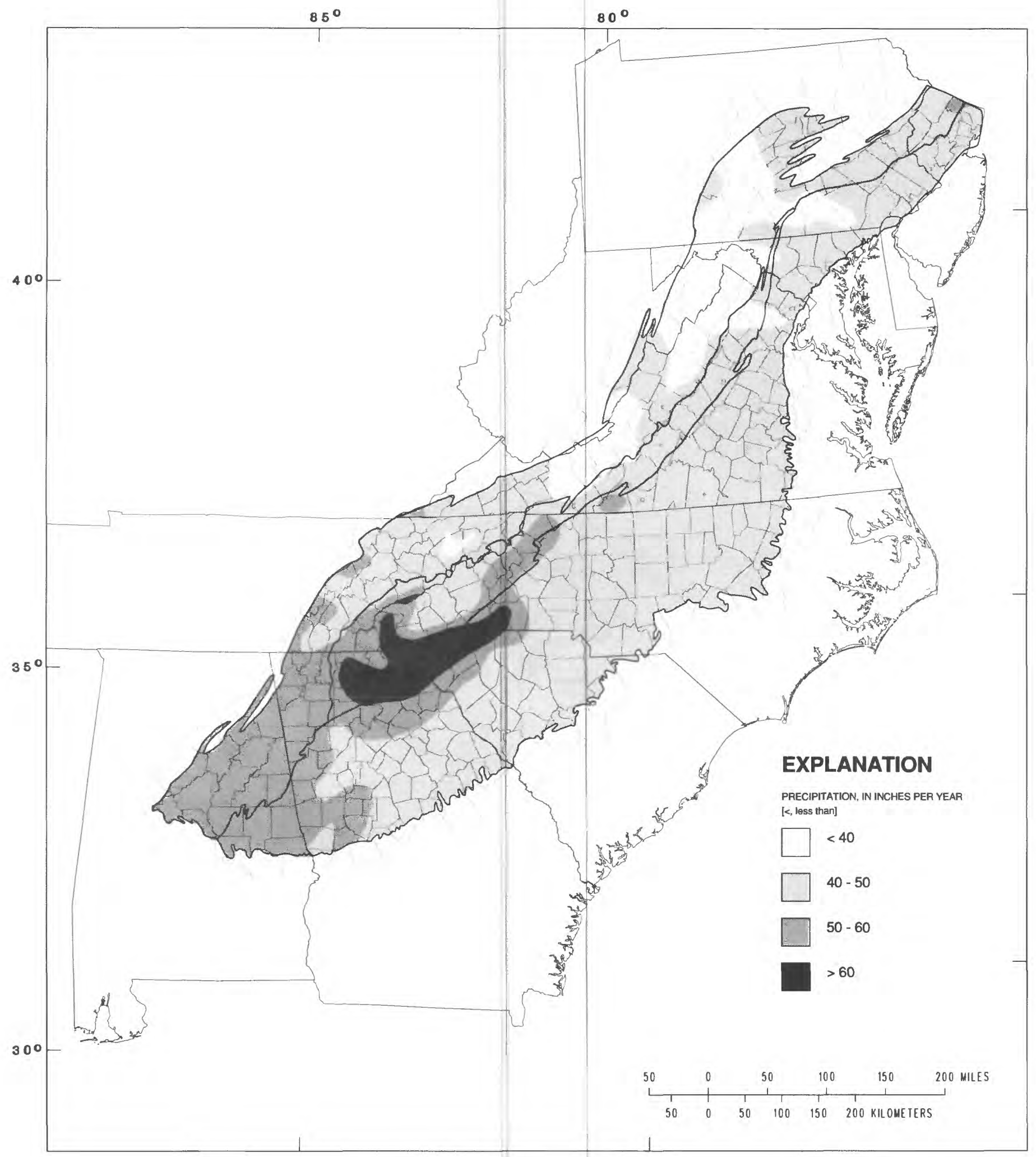

Figure 2.--Average annual precipitation, 1951-80. (Data from unpublished map compiled by D.A. Olson, National Oceanic and Atmospheric Administration, 1985.) 


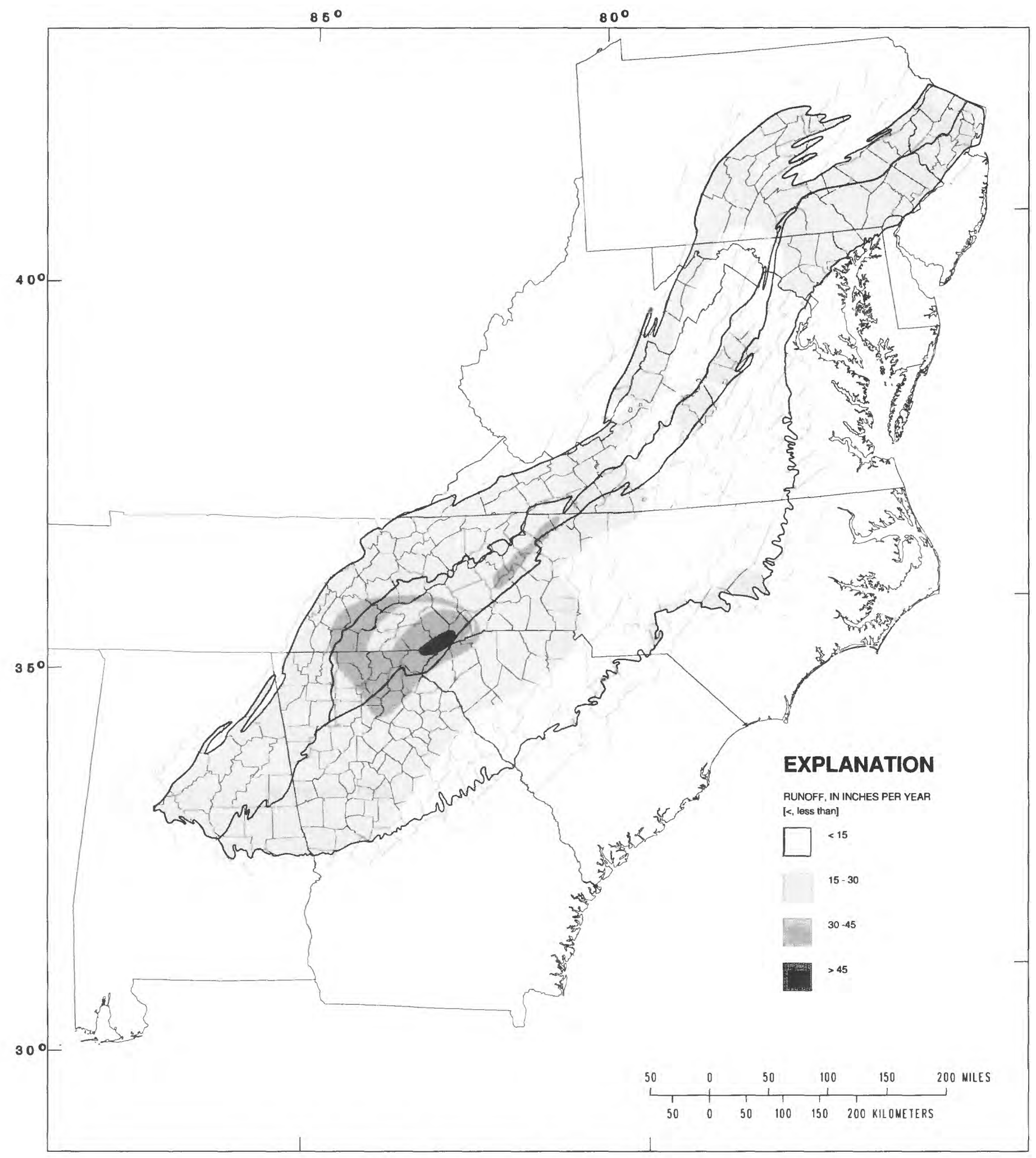

Figure 3.--Average annual runoff, 1951-80. (Data from Gebert and others, 1987.) 


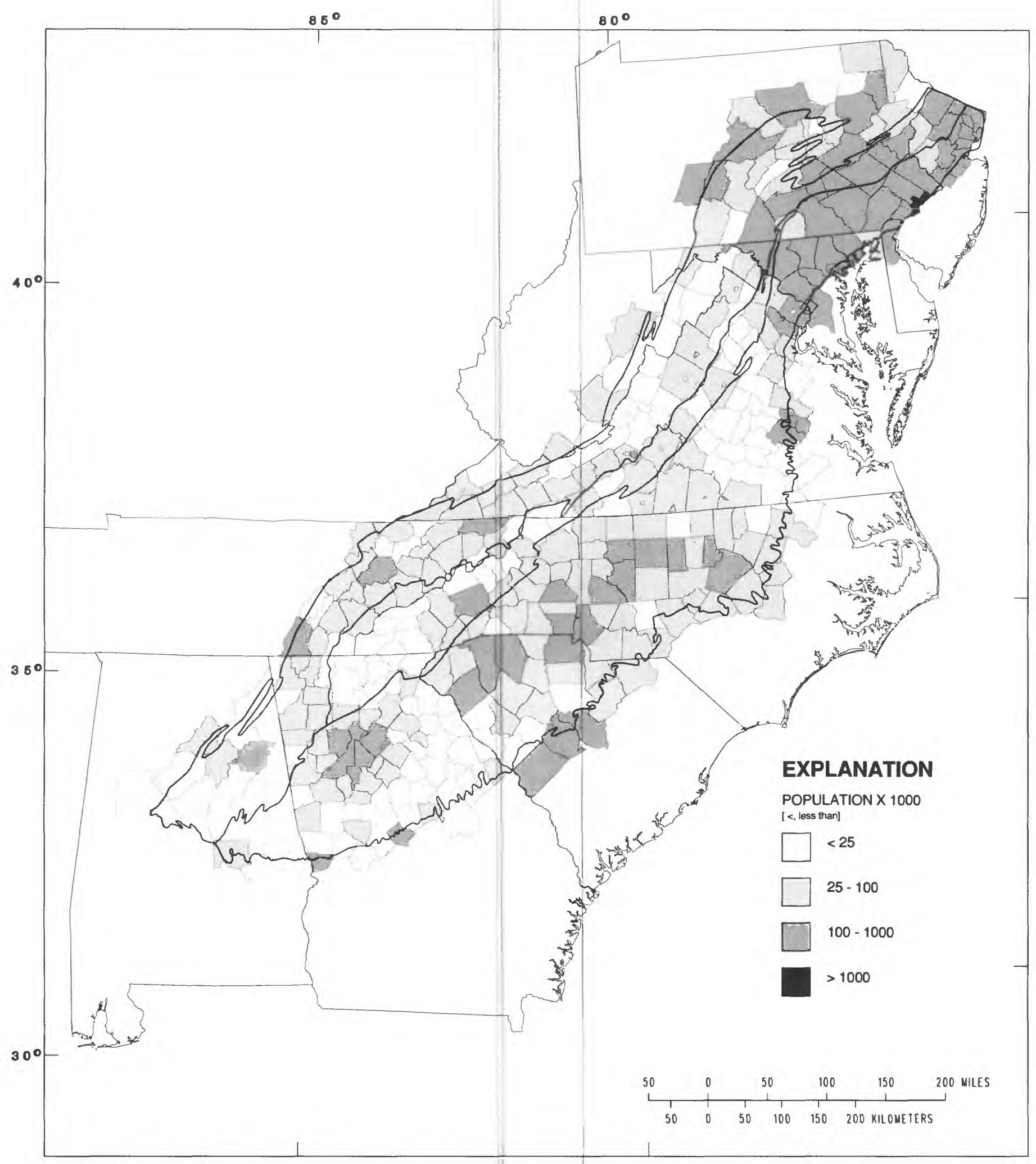

Figure 4.--Population distribution by county, 1985. (Data from U.S. Bureau of Census.) 


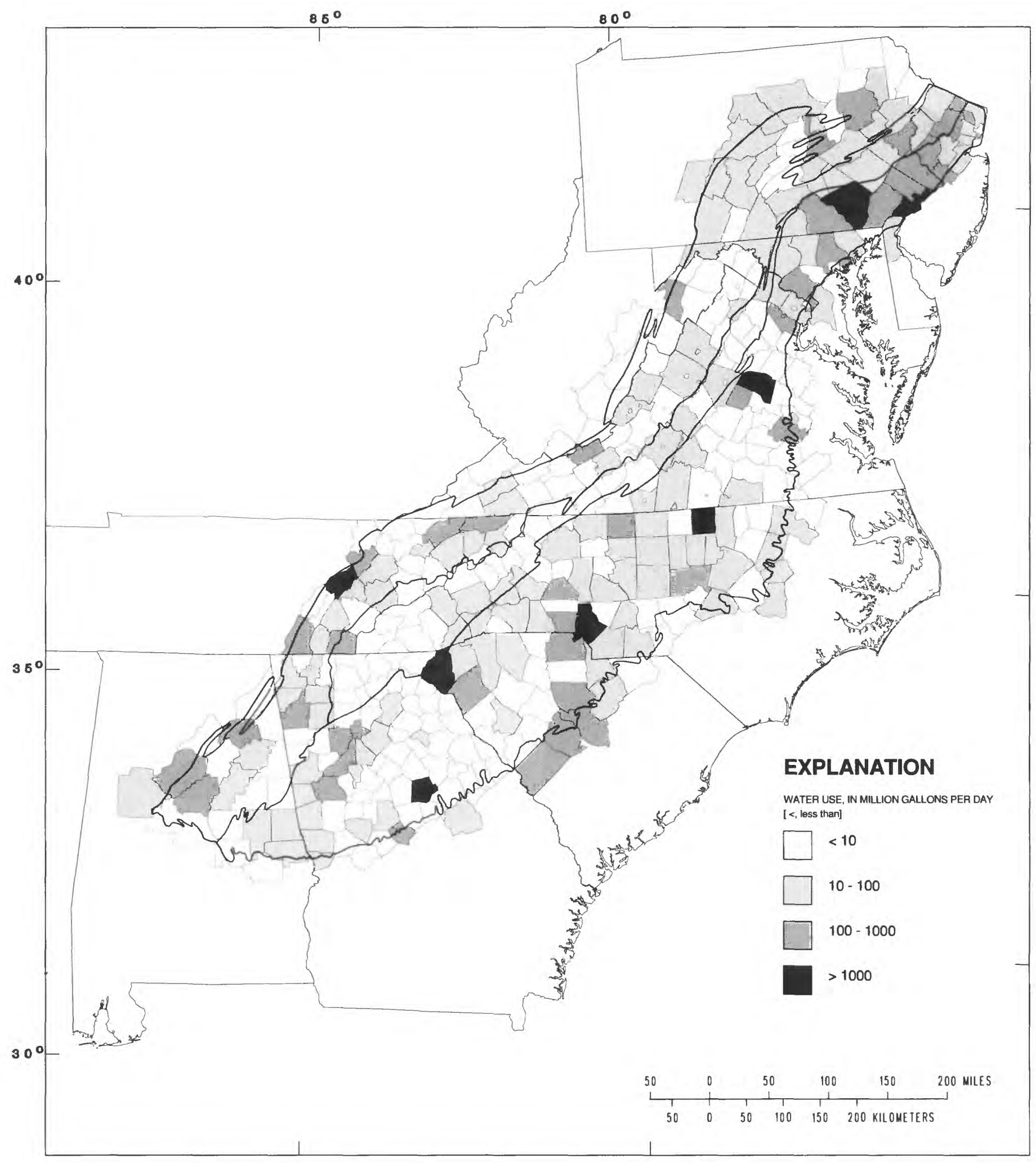

Figure 5.--Total water use by county, 1985. " (Data from U.S. Geological Survey National Water Data Storage and Retrieval Systems.) 
Table 2.-Ground- and surface-water use in the study area by state and physiographic province, 1985

[All data in million gallons per day, columns may not add to totals because of independent rounding. Data from U.S. Geological Survey National Water Data and Retrieval Systems]

\begin{tabular}{|c|c|c|}
\hline \multirow{2}{*}{$\begin{array}{c}\text { State } \\
\text { or } \\
\text { physiographic } \\
\text { province }\end{array}$} & \multicolumn{2}{|c|}{ Water use } \\
\hline & $\begin{array}{l}\text { Ground } \\
\text { water }\end{array}$ & $\begin{array}{c}\text { Surface } \\
\text { water }\end{array}$ \\
\hline Al abama & 94 & 1,420 \\
\hline Delaware & 15 & 49 \\
\hline District of Columbia & 0 & 348 \\
\hline Georgia & 151 & 3,260 \\
\hline Maryland & 81 & 1,170 \\
\hline New Jersey & 294 & 1,300 \\
\hline North Carol ina & 187 & 7,170 \\
\hline Pennsylvania & 495 & 8,400 \\
\hline South Carolina & 48 & 4,900 \\
\hline Tennessee & 99 & 3,510 \\
\hline Virginia & 217 & 4,170 \\
\hline West Virginia & 35 & 931 \\
\hline Total & 1,720 & 36,600 \\
\hline Piedmont province & 986 & 25,500 \\
\hline Blue Ridge province & 163 & 2,940 \\
\hline \multicolumn{3}{|l|}{ Valley and Ridge } \\
\hline province. & 567 & 8,130 \\
\hline Total & 1,720 & 36,600 \\
\hline
\end{tabular}

About 50 percent of surface-water flow in the region is derived from ground water; therefore, surface-water hydrology needs to be taken into account in descriptions of the groundwater system. In parts of the study area, surface-water resources are allocated for use on the basis of established legal decrees. During recent droughts, however, surface-water supplies have been insufficient to meet these allocations. As a result, pumping of ground water increased, which in turn decreased the amount of ground-water discharge to streams and resulted in a net loss of streamflow.

\section{RELATION TO OTHER REGIONAL AQUIFER- SYSTEM ANALYSIS STUDIES}

Three other RASA studies have been completed for areas adjacent to this study area (fig. 6). These are the Northern Atlantic Coastal Plain, Southeastern Coastal Plain, and Northeastern Glacial Valleys RASA's. Generally, aquifers in the Valley and Ridge and Piedmont physiographic provinces discharge water as base flow to streams within the APRASA study area. In places where the Valley and Ridge and Piedmont physiographic provinces are adjacent to the Coastal Plain, some aquifers discharge water from the study area by underflow directly to aquifers in the Coastal Plain. Aquifers in the Northeastern Glacial Valleys are considered to be local, independent aquifers, and sustained exchange of flow between those aquifers and aquifers in the APRASA study area is estimated to be negligible.

\section{ACKNOWLEDGMENTS}

The authors wish to acknowledge the significant contributions of two other USGS hydrologists, Thomas O. Mesko and Winfield G. Wright, in preparing the early versions of this report, We thank them for their time and efforts.

\section{GEOLOGIC SETTING AND FRAMEWORK}

The APRASA study area can be considered as two distinct subareas on the basis of differences in geology and hydrologic characteristics. The first subarea consists of carbonate rock, sandstone, and shale of the Valley and Ridge physiographic province and the extreme western part of the Blue Ridge physiographic province. 


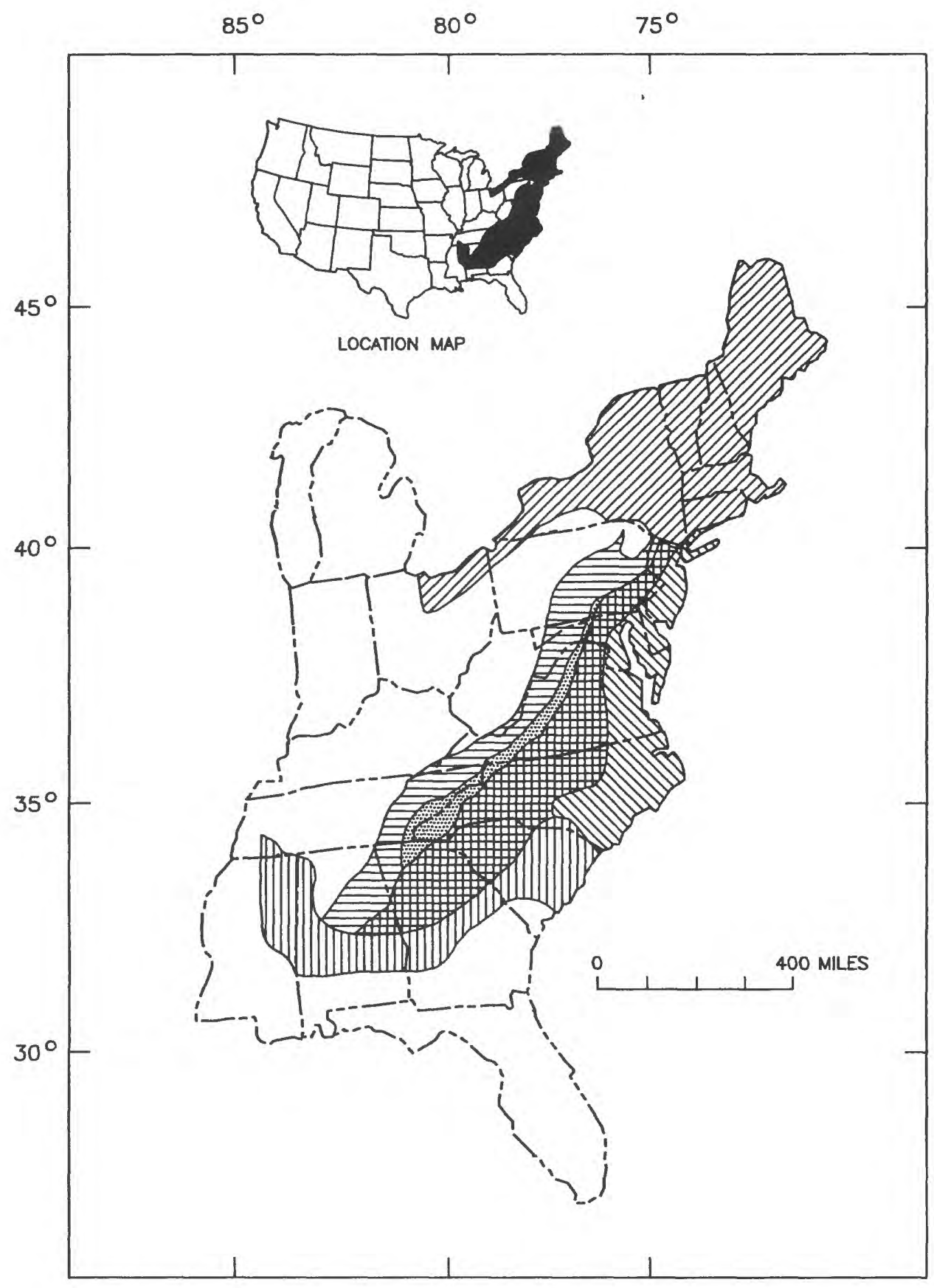

\section{EXPLANATION}

APPALACHIAN VALLEYS-PIEDMONT REGIONAL AQUIFER-SYSTEM ANALYSIS STUDY AREA

Valley and Ridge physiographic province

Blye Ridge physiographic province

Piedmont physiographic province

ADJACENT REGIONAL AQUIFER-SYSTEM

ANALYSIS (RASA) STUDY AREAS

Northern Atlantic Coastal Plain RASA

IIIII Southeastern Coastal Plain RASA

QT Northeastern Glacial Valleys RASA

Figure 6.--Location of the Appalachian Valleys-Piedmont Regional Aquifer-System Analysis study area in relation to adjacent Regional Aquifer-System Analysis study areas. (Modified from Sun, 1986, fig. 2.) 
The second subarea consists of metamorphic and igneous crystalline rocks in the Piedmont physiographic province and central and eastern Blue Ridge physiographic province. Large rift basins, extending from New Jersey to South Carolina within the Piedmont crystalline rocks, have been filled with sedimentary deposits of early Mesozoic age. Glaciation covered only a small part (about 3,000 $\mathrm{mi}^{2}$ ) of the study area in eastern Pennsylvania and New Jersey. Locally, glacial deposits can provide significant quantities of water, but these deposits are not regionally significant.

Regolith, consisting of soil, alluvium, and weathered rock material overlies most of the geologic units throughout both subareas. In some locations, it includes material that has been transported and deposited as glacial drift, colluvium, or alluvium. In other locations, the regolith consists only of weathered material called residuum or saprolite, which remains atop the parent rock from which it has been derived. Thickness of the regolith throughout the study area is extremely variable and ranges from 0 to more than $150 \mathrm{ft}$. At some locations, the rate of weathering is approximately equal to the rate at which weathered material is removed by erosion; thus, thickness of regolith remains fairly constant.

Regolith can be divided into three horizons: the soil zone, saprolite, and a transition zone between saprolite and unweathered bedrock. Where the regolith does not include material that has been transported, the three horizons represent stages in the breakdown of bedrock in response to weathering. The weathering process is greatly influenced by the climate of an area; a warm, humid environment such as that of the eastern and southeastern United States favors the development of a thick layer of regolith. Bedrock is typically exposed only in areas of rugged topography or in stream channels where erosion has removed the regolith.

\section{VALLEY AND RIDGE PHYSIOGRAPHIC PROVINCE}

The valleys of the Valley and Ridge physiographic province are separated by parallel ridges formed in part as a result of thrust faulting and folding. Ridge development is controlled by geologic structure and weathering characteristics of the different rock types. Generally, ridges are underlain by conglomerate, sandstone, or cherty dolomite, whereas valleys are underlain by siltstone, shale, limestone, or dolomite that is not as resistant to weathering as rocks forming the ridges.

The sedimentary rocks that underlie the Valley and Ridge physiographic province range in age from Cambrian to Pennsylvanian. The deposits that formed these rocks were dominantly shelf carbonates and basin siliciclastics. Carbonate rocks of particular importance to water supply are found in the Cambrian System, in the Lower and Middle Ordovician Series, and in the Mississippian System. Significant amounts of chert or disseminated quartz sand, which appear to be associated with deeper-than-average weathering of the rocks, are found in carbonate rocks in the Upper Cambrian, Lower Ordovician, and Lower Mississippian Series. Quartzite and sandstone of particular importance to water supply are present in the Silurian, Devonian, and Carboniferous Systems. Throughout the southern three-quarters of the province, a hydrologically significant paleokarst is present in carbonate rocks in the Lower Ordovician Series (Mussman and others, 1988). Diabase dikes of Mesozoic or Eocene age cross the area in southcentral Pennsylvania and western Virginia (King and Beikman, 1974).

Structurally, the Valley and Ridge physiographic province has been intensely deformed as a result of several mountain-building events. Rocks were tilted and faulted into a series of disharmonic sheets that were thrust from the southeast several tens of miles to the west or northwest. At land surface, the northern half of the province is dominated by folds and abundant localized fracturing, whereas the southern half 
of the province is dominated by major thrust faults. At depth, major thrust faults exist in both parts of the province (Woodward, 1985). Folds and thrust faults cause the rocks to crop out in a series of northeast-trending strike belts in which the formations are commonly repeated. Significant fracturing of rocks has occurred throughout the province.

\section{PIEDMONT AND BLUE RIDGE PHYSIOGRAPHIC PROVINCES}

The Piedmont and Blue Ridge physiographic provinces are underlain by igneous, metamorphic, and sedimentary bedrock ranging in age from Precambrian to Mesozoic. Types of rocks include massive granites and gneisses, foliated phyllites and schists, and consolidated sandstones. Sedimentary rocks of early Mesozoic age fill rift basins within the Piedmont physiographic province (fig. 7). Sedimentation was accompanied by igneous and volcanic activity where basaltic and diabase dikes were intruded into the Mesozoic sedimentary rocks. Rocks that crop out in the Piedmont underlie parts of the Atlantic Coastal Plain at depth. Because of significant geologic and hydrologic differences, the Piedmont and Blue Ridge physiographic provinces have been divided into two groups: (1) crystalline-rock regimes and (2) sedimentary-rock regimes.

\section{Crystalline-Rock Regimes}

Metamorphic and igneous crystalline rocks underlie most of the Piedmont and Blue Ridge area; metamorphic rocks are the more abundant. Metamorphic and igneous rocks in the province range in composition from felsic to ultramafic and range in age from Middle Proterozoic for granitic rocks in the Blue Ridge (Tilton and others, 1960) to Triassic-Jurassic for the unmetamorphosed dikes and sills of mafic composition that intrude the Piedmont (Ragland and others, 1983; Weigand and Ragland, 1970).

Bedding and foliation within metamorphic bedrock are usually folded and tilted, can exhibit variable orientations, and commonly intersect one another in systematic geometric patterns. Bedrock generally is weathered to saprolite; however, the relict structure and directional properties controlling permeability or hydraulic conductivity are retained in places. Although most rocks in the area have been metamorphosed and have strong directional fabrics, igneous intrusives emplaced after the last metamorphic event in the late Paleozoic tend to be massive and less foliated. Most of the rocks were subjected to uplift during the Cenozoic Era and subsequent weathering and erosion, which opened or widened existing fractures and created new ones by stress relief. Fault zones of different types, scales, and orientations are common; some are characterized by an abundance of fractures.

\section{Sedimentary-Rock Regimes}

Several sedimentary basins within the Piedmont physiographic province contain rocks of early Mesozoic age (fig. 7). They consist of a series of elongate, down-faulted basins that crop out in a discontinuous belt almost $600 \mathrm{mi}$ long from southeastern New York to South Carolina. Basins are exposed at land surface in parts of the Piedmont physiographic province but are covered by as much as several thousand feet of Cretaceous and younger sediments in the Coastal Plain. These basins formed in Triassic and Jurassic time during the incipient rifting of the continents. Concurrently, they were filled with thick sequences of continental sediment eroded from surrounding crystalline highlands. In most of the study area, these continental sediments, along with interbedded basaltic lava flows, have been assigned to the Newark Supergroup (Froelich and Olsen, 1985). These Mesozoic deposits lie unconformably on Precambrian and Paleozoic crystalline rocks.

Sedimentary rocks of the Newark Supergroup consist predominantly of interbedded red shale, sandstone, and siltstone. Locally, conglomerate and lacustrine black mudstone are common and coal is present in the 


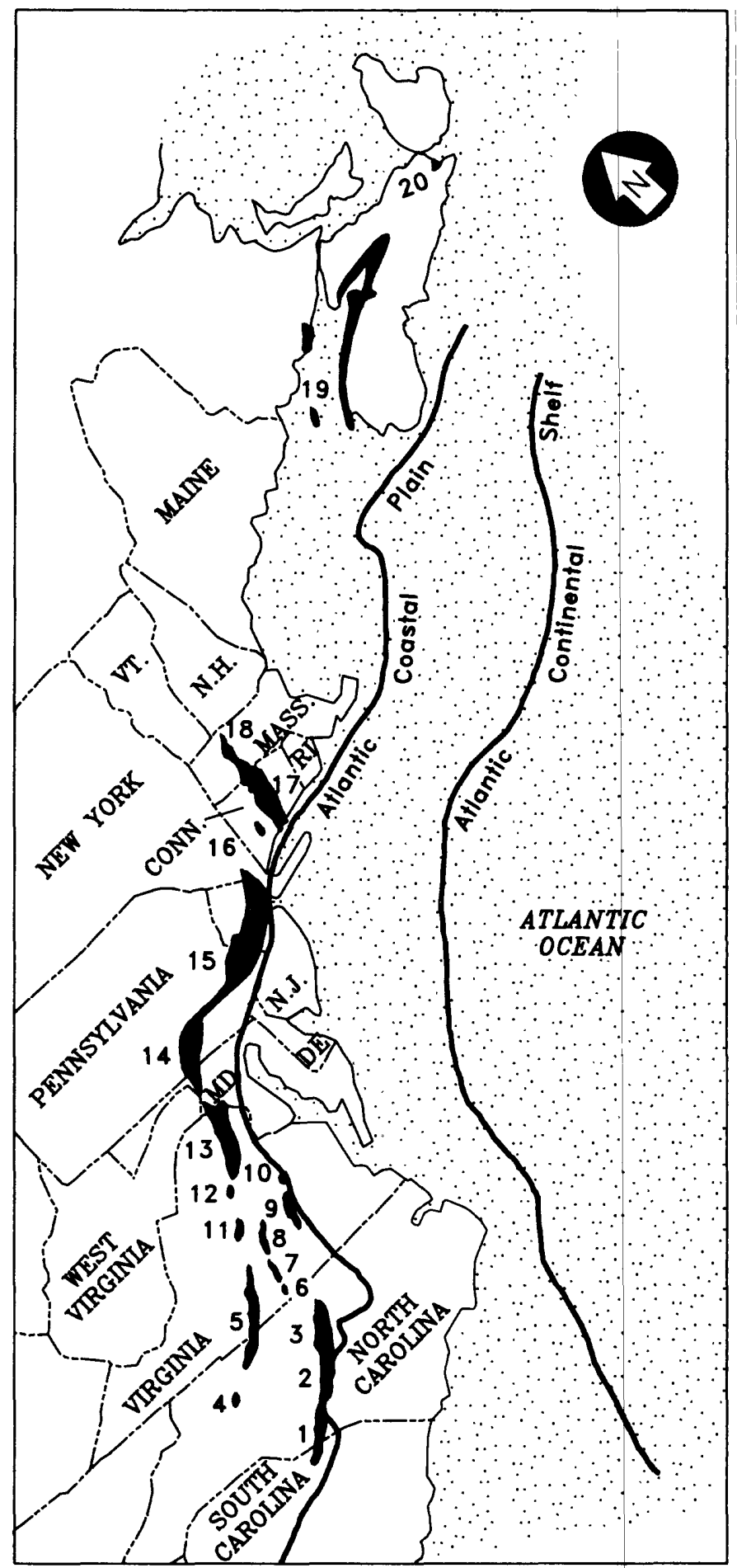

EXPLANATION

EARLY MESOZOIC BASIN AND NUMBER

1 Wadesboro (N.C.-S.C.)

2 Sanford (N.C.)

3 Durham (N.C.)

4 Davie County (N.C.)

5 Dan River and Danville (N.C.-Va.)

6 Scottsburg (Va.)

7 Basins north of Scottsburg (Va.)

8 Farmville ( $\mathrm{Va}$.)

9 Richmond ( $\mathrm{Va}$. )

10 Taylorsville (Va.)

11 Scottsville ( $\mathrm{Vo}$. )

12 Barboursville (Va.)

13 Culpeper (Va.-Md.)

14 Gettysburg (Md.-Pa.)

15 Newark (N.J.-Pa.-N.Y.)

16 Pomperaug (Conn.)

17 Hartford (Conn.-Mass.)

18 Deerfield (Mass.)

19 Fundy or Minas

(Nova Scotia-Canada)

20 Chedabucto (Nova

Scotia-Canoda)

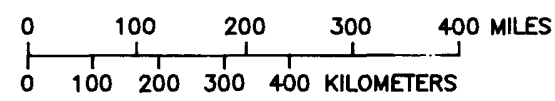

Figure 7.--Exposed early Mesozoic basins in eastern North America. (From Smoot and Robinson, 1988, fig. 1.) 
Richmond, Va., Danville and Deep River basins of North Carolina (fig. 7). Although not included as part of the Newark Supergroup, intrusive dikes and sills predominantly composed of diabase are common in and adjacent to the early Mesozoic basins.

Structurally, most geologic formations within the early Mesozoic basins strike northeast and dip toward the main border fault, commonly northwest or southeast, between 5 to 40 degrees. Thickness of Triassic and Jurassic deposits in the largest of the basins has been calculated to be in excess of $20,000 \mathrm{ft}$.

\section{HYDROGEOLOGIC SETTING AND FRAMEWORK}

Understanding the hydrogeology of the APRASA study area is greatly complicated by the fact that the porosity and permeability in the rocks are almost exclusively secondary. As a result, the permeability is extremely variable. High or low permeability is not easily associated with a particular geologic formation or even a particular rock type. As a consequence, the usual approach of describing the hydrogeologic framework in terms of aquifers and confining units is devalued by the extreme variability in the permeability distribution which tends to obscure the distinction between aquifers and confining units. A more fruitful approach than to distinguish between aquifers and confining units is to divide the study area into hydrogeologic terranes that are based upon the distribution and magnitude of factors that are related to the occurrence of secondary porosity and permeability. For the purpose of this plan of study, a hydrogeologic terrane is defined as a combination primarily of rock type, regolith conditions, and topographic setting which is relatively homogeneous as to (1) water-yielding potential of the earth materials, as indicated by specific capacity of wells or base flow of streams; (2) ground-water storage; and (3) ground-water quality. At this time, it would appear that terranes are most easily distinguished primarily on the basis of rock type, and secondarily by consideration of rock texture, regolith thickness and texture, rock structure, topographic setting, and nongeologic factors. Not all factors are known. For those factors that affect porosity and permeability that are known, the degree of control is not known or differs significantly from place to place. Variability in the thickness and texture of the regolith, which can store a significant amount of ground water, also must be considered in addition to variability in the secondary permeability of the bedrock. All factors known or suspected to control the degree of secondary permeability will be tested using hydrologic criteria such as specific capacity or base flow.

The ground-water hydrology of the study area is best described in terms of conceptual flow systems. For the purpose of this plan of study, a conceptual flow system is in most cases the three-dimensional flow net that is conceived to exist within a hydrogeologic terrane. In accordance with work by Toth (1963), local and intermediate systems of ground-water flow have been identified in the study area. Local flow systems are commonly restricted to depths shallower than $600 \mathrm{ft}$ in the Valley and Ridge physiographic province and $800 \mathrm{ft}$ in the Piedmont and Blue Ridge physiographic provinces; they commonly lie between adjacent topographic divides that range from a few thousand feet to a few miles apart. The intermediate flow systems are believed to range in depth from 800 to $5,000 \mathrm{ft}$ and in places, to traverse adjacent topographic divides. The intermediate flow systems are believed to represent less than 5 percent of the total groundwater flow. The hydrogeologic terranes discussed in this report are more closely associated with the local flow systems than with the intermediate flow systems.

In the subsequent discussion, only one generic conceptual flow system is described and illustrated for the (1) folded rocks of the Valley and Ridge physiographic province; (2) crystalline rocks of the Piedmont physiographic province; and (3) the sedimentary basins in the Piedmont physiographic province. In addition, 
the deep, confined flow systems of the Valley and Ridge physiographic province are not illustrated. An example of a conceptual flow system for deep confined flow is presented in Hobba and others (1979, fig. 12 and fig. 13).

In subsequent discussion of the objectives of the study and the approach, the term "type area" applies to a 10- to $100-\mathrm{mi}^{2}$ area within a hydrogeologic terrane where information is sufficient to develop and test a concept of ground-water flow by use of analytic or numeric methods. Ideally, these type areas are selected to be representative of the flow system that is present wherever the particular hydrogeologic terrane is present.

\section{VALLEY AND RIDGE PHYSIOGRAPHIC PROVINCE}

The wet climate and presence of carbonate rock in this province favor the development of karst features such as sinkholes, solution cavities, and large springs (U.S. Geological Survey, 1970; Newton, 1987). The largest groundwater supplies in the Valley and Ridge province are obtained from soluble carbonate rocks, especially where such rocks are associated with thick regolith. Areal variability in thickness of regolith is common throughout the Valley and Ridge physiographic province (DeBuchananne and Richardson, 1956). For the purposes of this study, thick regolith ranges from 50 to more than $150 \mathrm{ft}$; thin regolith is less than $50 \mathrm{ft}$ in thickness. Where regolith is thick, it acts as a storage reservoir for recharge, which is slowly and almost continuously released and allowed to percolate downward. The underlying carbonate rocks are dissolved to greater depths in areas where regolith is thick than where regolith is thin.

With few exceptions, rocks of the Valley and Ridge physiographic province have low primary porosity and permeability. In about the upper $300 \mathrm{ft}$ of these rocks, however, fracturing and dissolution have produced substantial secondary porosity and permeability. Wells commonly produce from 5 to $500 \mathrm{gal} / \mathrm{min}$ (gallons per minute) from these secondary openings, and the yield from a single well in a large dissolution opening can exceed 3,500 $\mathrm{gal} / \mathrm{min}$ (U.S. Geological Survey, 1985, p. 180).

Ground-water flow within the Valley and Ridge physiographic province is generally restricted by parallel ridges and discharges to local streams. The local streams are normal to the axes of the intervening valleys and are tributary to the main streams that flow along the axes of the valley. In places, main streams cut across or through the ridges. Thus topography, combined with ridge-cutting main streams effectively compartmentalizes ground-water flow into adjacent, but hydraulically isolated, shallow flow systems (fig. 8). Such shallow flow systems are numerous in the Valley and Ridge physiographic province. In each flow system, ground water flows from ridge to valley until the water either discharges directly to local streams or is intercepted and routed downvalley by a layer or zone of rocks in which secondary permeability is well-developed. Generally, flow paths parallel to the axis of the valley are several times longer than flow paths perpendicular to the axis of the valley. The highly permeable zones typically contain minor amounts of fine-grained, insoluble residue and commonly are coarse-grained carbonate rocks with well-developed dissolution openings. In places, these zones contain fractures that act as collectors or conduits. Flow components that are parallel to the axis of the valley commonly discharge to a spring or a main stream that crosses the valley (Parizek and others, 1971; Hollyday and Goddard, 1979). In contrast to this conduit flow in carbonate rocks, flow in siliciclastic rocks tends to be diffuse.

\section{Hydrogeologic Terranes and Conceptual Ground-Water-Flow Systems}

The hydrogeologic terranes and conceptual flow systems that have been identified for the study area thus far in the Valley and Ridge physiographic province are described in table 3 

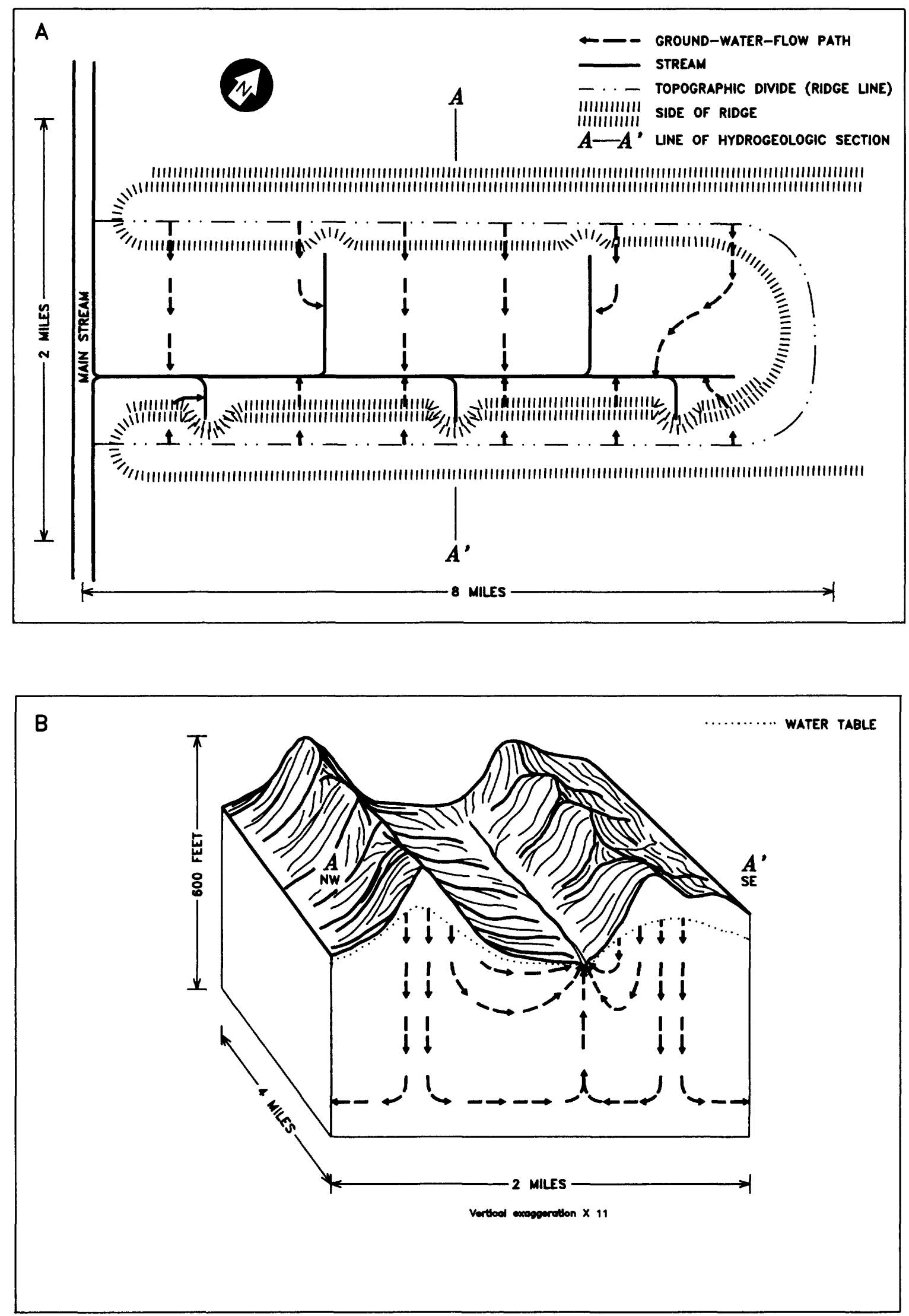

Figure 8.--Idealized (A) plan and (B) sectional views of a typical local ground-water-flow system in the Valley and Ridge physiographic province. 


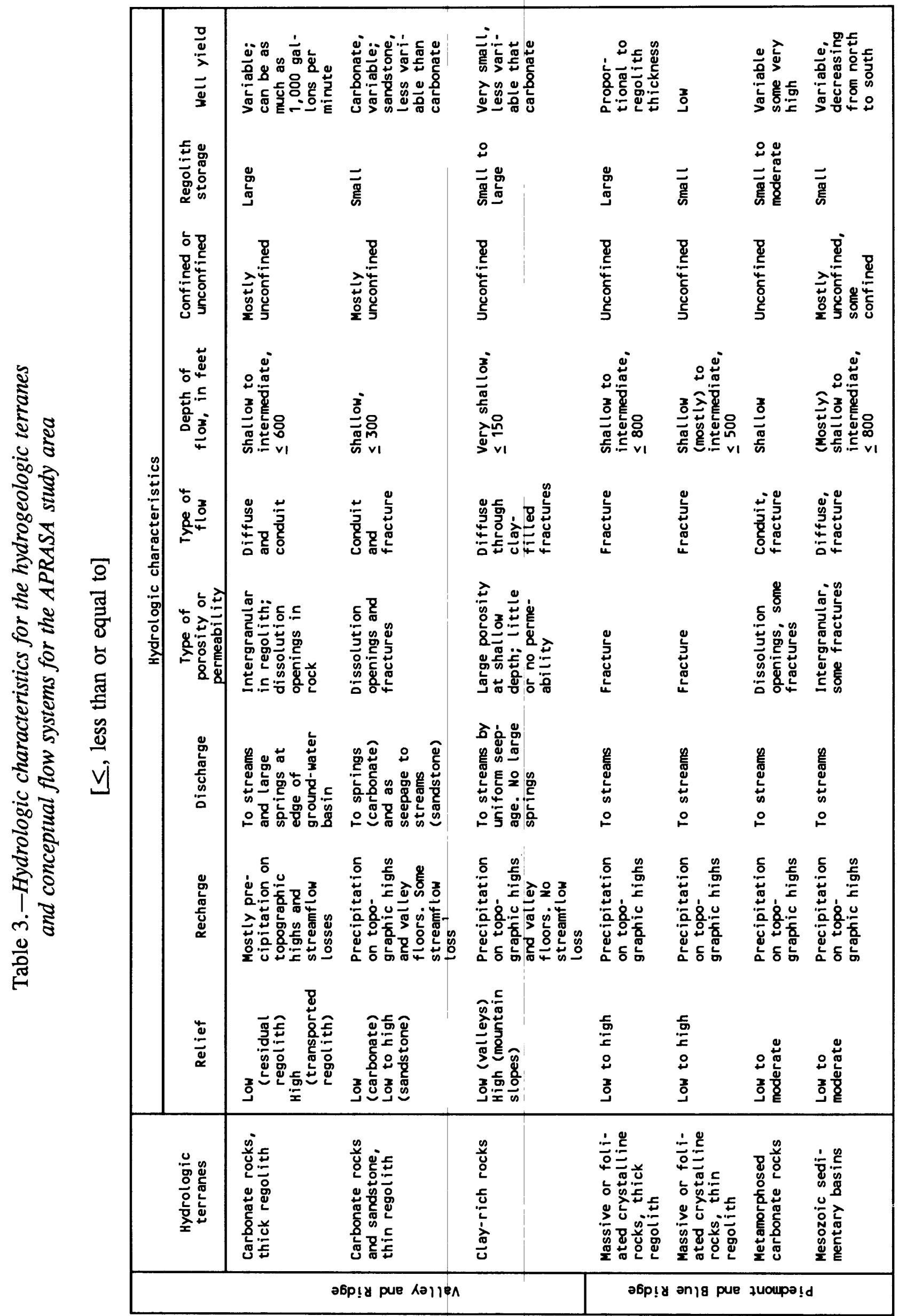




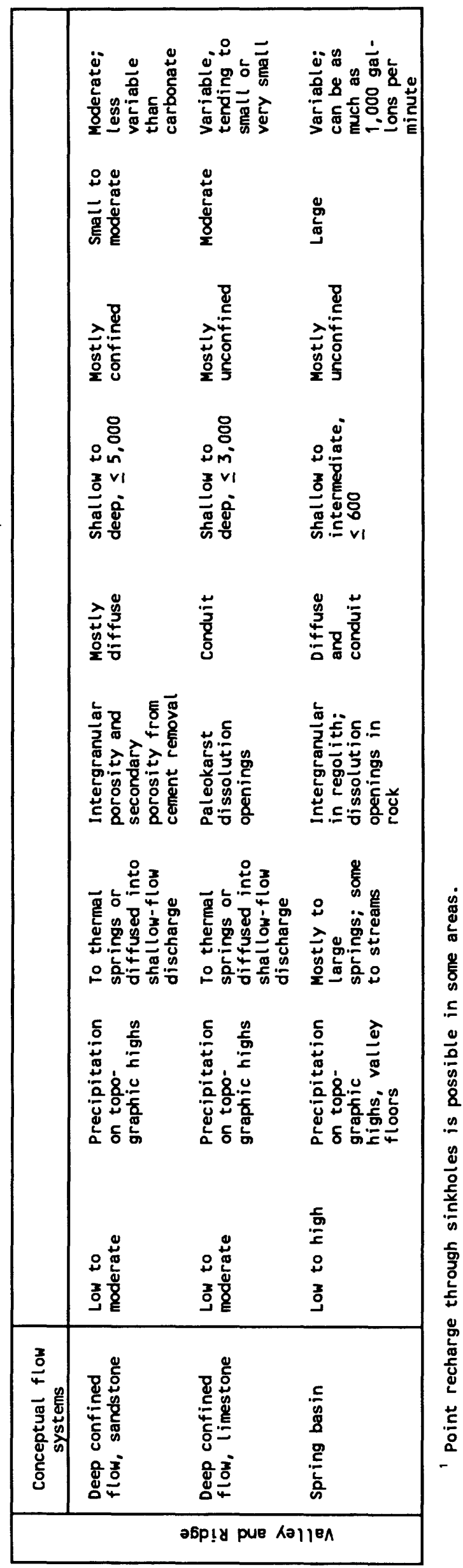


and are further described below. The hydrogeologic terranes, which are associated with local flow systems, are (1) carbonate rocks mantled by thick regolith; (2) carbonate and sandstone rocks mantled by thin regolith; and (3) clay-rich rocks mantled by regolith. The conceptual local flow system is termed the "spring-basin flow system." The conceptual intermediate flow system is termed the "deep, confined flow system."

\section{Carbonate rocks mantled by thick regolith}

The most productive hydrogeologic terrane in the Valley and Ridge physiographic province consists of carbonate rocks that are overlain by coarse-grained, thick regolith (fig. 9). Carbonate rocks of Early Mississippian age in Alabama, Georgia, and southeastern Tennessee are covered by thick chert rubble locally derived from the bedrock. Transported regolith (colluvium and alluvium) is present along the entire length of the southeastern margin of the Valley and Ridge physiographic province. Along this margin, carbonate rocks of Cambrian age are covered in more than two dozen locations by coarse quartzite rubble derived from nearby ridges. These ridges are capped predominantly by sandstone of Early Cambrian age along the northwestern margin of the adjacent Blue Ridge physiographic province. Along the northwestern margin the southern half of the Valley and Ridge physiographic province, carbonate rocks of Mississippian age are covered in several places by coarse orthoquartzite rubble derived from rocks capping the escarpment of the southeastern margin of the adjacent Appalachian Plateaus physiographic province. In places, transported regolith covers carbonate rocks on the slopes of mountains capped by Silurian sandstone and conglomerate in the middle of the Valley and Ridge physiographic province. Wells completed in carbonate rocks covered by coarse, thick regolith are capable of yielding more than $1,000 \mathrm{gal} / \mathrm{min}$.

\section{Carbonate and sandstone rocks mantled by thin regolith}

A second hydrogeologic terrane consists of carbonate rock and clay-rich sandstones mantled by thin regolith. This terrane produces moderate to large amounts of water. An example of this hydrogeologic terrane is the limestone rocks of Middle Ordovician age in the Great Valley of Pennsylvania. Arkose and graywacke of Silurian and Devonian age also are considered to be representative of this terrane.

\section{Clay-rich rocks mantled by regolith}

The least productive terrane consists of shale or clay-rich carbonate rocks. Examples are the black and gray shales of Devonian age in the northeastern half of the Valley and Ridge physiographic province and the Rome Formation of Early and Middle Cambrian age in Tennessee. Examples of clay-rich carbonate rocks can be found in the middle part of the Conasauga Group of Middle and Late Cambrian age along the northwestern margin of the Valley and Ridge physiographic province in Tennessee. This terrane is similar to the one in the crystalline rocks of the Piedmont physiographic province in that ground-water flow in many places is mostly in intergranular openings in the regolith rather than in fractures in the bedrock. Wells completed in this terrane typically yield water at rates that range from less than 1 to 15 $\mathrm{gal} / \mathrm{min}$.

\section{Deep, confined flow systems}

At least two deep ground-water flow systems are believed to be moderately productive. Except where exposed at land surface, the aquifers that contain these flow systems are overlain by much less permeable rocks and contain water mostly under confined conditions. One flow system is associated with orthoquartzite sandstones in which carbonate cementation is either poor or has been removed by dissolution. Most flow in this system is 


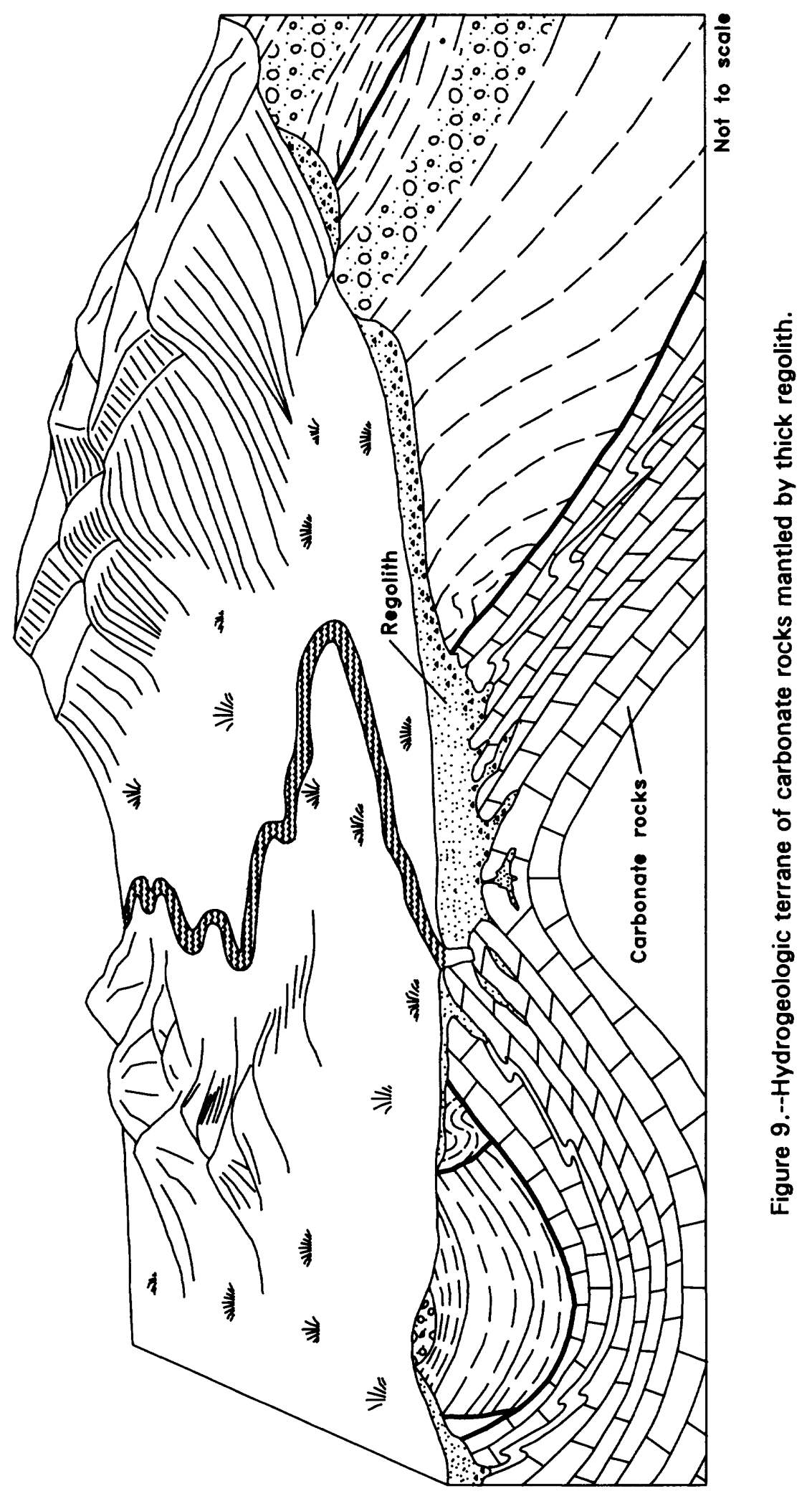


intergranular and diffuse. Examples of this system include sandstone of Devonian age and equivalent rocks that are overlain by many hundreds of feet of Devonian shale in much of the northern Valley and Ridge physiographic province. The other flow system is associated with paleokarsts in carbonate rocks of Early Ordovician age in much of the middle and southern Valley and Ridge physiographic province. Flow in this latter system is mostly conduit flow.

\section{Spring-basin flow systoms}

A large subsurface drainage system commonly develops where regolith is thick, rock is soluble, and folds, faults or fractures enhance underground flow and storage. Much of the ground water in such a system discharges at one or more large springs. In the Valley and Ridge physiographic province, there are no springs with average flows greater than $100 \mathrm{ft}^{3} / \mathrm{s}$ (cubic feet per second); however, there are about 50 springs whose average flows are between 10 and $100 \mathrm{ft}^{3} / \mathrm{s}(4,490$ and 44,900 $\mathrm{gal} / \mathrm{min}$ ) and numerous springs whose flows are less than $10 \mathrm{ft}^{3} / \mathrm{s}$. Water budgets for large springs in the Valley and Ridge physiographic province could be similar to the budgets for Schantz Spring, Lehigh County, Pa. (Wood and others, 1972), or for Boiling Spring and Baker Spring, Cumberland County, $\mathrm{Pa}$. (Becher and Root, 1981). If so, then the subsurface drainage basin of a spring with an average flow of $10 \mathrm{ft}^{3} / \mathrm{s}$ would be expected to be about $10 \mathrm{mi}^{2}$. Spring basins are elongated in the direction of strike. Wells completed in spring basins are capable of yielding a few thousand gallons of water per minute.

\section{Ground-Water Quality}

Natural quality of ground water in the Valley and Ridge physiographic province is affected by the residence time of water within the aquifer, depth of circulation, and mineral composition of the rock matrix. In shallow flow systems, dissolved-solids concentrations in water from springs and wells commonly range from 50 to $500 \mathrm{mg} / \mathrm{L}$ (milligrams per liter) (Brahana and others, 1986). The predominant water types are calcium-magnesium bicarbonate (the most common type) and calciummagnesium sulfate-chloride type water. Magnesium concentrations are generally higher in water from dolomite than in water from limestone. Therefore, the ratio of calcium to magnesium in water samples can be used to infer which of these rocks form the predominant aquifer in a given area. Concentrations of iron, manganese, and hydrogen sulfide concentrations are typically higher in water from shale than in water from carbonate rocks.

Water from wells that tap deep aquifers with low hydraulic conductivities typically is similar in type to water from wells that tap shallower aquifers with greater hydraulic conductivities; however, ground water below a depth of $200 \mathrm{ft}$ has about twice the dissolvedsolids concentration of water at about $50 \mathrm{ft}$. Oil- and gas-exploration wells have produced brine (water whose dissolved-solids concentration is greater than $35,000 \mathrm{mg} / \mathrm{L}$ ) from permeable zones at depths generally greater than 4,000 ft. Most fluids at these depths are found in paleokarst within Lower Ordovician rocks.

\section{PIEDMONT AND BLUE RIDGE PHYSIOGRAPHIC PROVINCES}

The hydrogeology of the Piedmont and Blue Ridge physiographic provinces is different than that of the Valley and Ridge physiographic province mainly in that there is not the propensity for the aquifer material in the Piedmont and Blue Ridge physiographic provinces to form large dissolution cavities. In addition, in the Mesozoic basins where primary permeability exists, the well-yielding characteristics are usually more consistent with time than in other rocks of the APRASA study area. Wateryielding characteristics of the various hydrogeologic terranes within the Piedmont and Blue Ridge physiographic provinces is very 
dependent upon the thickness of the regolith or the transition zone. As a result, once the regolith has been significantly drained of its water, the volume of well yield per unit of water level decline may also decrease significantly.

\section{Rock Regimes}

Similar to the Geologic Setting and Framework, the hydrogeology of the Piedmont and Blue Ridge physiographic provinces can be divided initially into two distinct regimes based on differences in lithology. These two regimes are the crystalline-rock regime for the majority of the Piedmont and Blue Ridge physiographic provinces, and the sedimentary-rock regime for the early Mesozoic basins.

\section{Crystalline-rock regimes}

The principal components of the groundwater system in the crystalline-rock regimes of the Piedmont and Blue Ridge physiographic provinces are illustrated schematically in figure 10. In most places, the consolidated rocks are overlain by regolith. Porosity of the regolith is on the order of 35 to 55 percent (Stewart, 1962) near land surface but decreases with depth as the degree of weathering decreases. Porosity of the bedrock can range from only 0.01 to 2 percent (Heath, 1984). Because of the relatively high porosity and permeability of the regolith, recharge from precipitation is stored in the regolith and later reaches the underlying rocks through fractures. The storage and transmitting characteristics of the bedrock and regolith and the hydrologic relation between them determines the watersupply potential of the aquifers in crystallinerock regimes of the Piedmont and Blue Ridge physiographic provinces. Wells penetrating consolidated rocks in areas mantled by thick saturated regolith generally have higher sustained yields than wells where regolith is thin or absent.
The transition zone between overlying saprolite and the unweathered rock below is often more permeable than the saprolite is. If the transition zone is sufficiently thick, then lateral ground-water movement can take place in this zone (Stewart and others, 1964; Nutter and Otton, 1969). The increased permeability of the transition zone is a result of the hydration of feldspar minerals which causes a separation of the platy structure of the rock. Where the weathering process has proceeded further as in the saprolite above the transition zone, the feldspars are chemically altered to clay-size particles, and reduced permeability results. Laboratory analyses of samples of saprolite overlying crystalline rocks of the Piedmont physiographic province in Maryland and Georgia indicate a wide range of permeabilityfrom about $0.0013 \mathrm{ft} / \mathrm{d}$ (foot per day) to about $15.4 \mathrm{ft} / \mathrm{d}$ (Nutter and Otton, 1969).

The abundance of connected fractures within the bedrock directly affects the yield of wells in the Piedmont physiographic province (Powell and Abe, 1985: Heath, 1984). Because fractures act as conduits for the flow of ground water, well yields are greatest where wells intersect numerous fractures or large fractures. The number and size of fractures decreases with depth in the Piedmont rocks. Consequently, most wells within the Piedmont are less than $800 \mathrm{ft}$ deep. Wells in the crystalline rocks of the Piedmont commonly produce from 5 to 35 $\mathrm{gal} / \mathrm{min}$ and occasionally may yield more than $1,800 \mathrm{gal} / \mathrm{min}$ (McGreevy and Sloto, 1977).

Several studies have indicated the strong relation between topography and well yields. Nutter and Otton (1969) found that wells drilled in valley floors have 3 to 4 times the yield of wells drilled on hilltops. In a study of well yields for different topographic locations in the southern Piedmont of Virginia, LeGrand (1960) found that wells in valleys or draws have substantially higher yields than do wells on slopes and hilltops.

Fractures, bedding planes, and foliation create inhomogeneity in the distribution of 


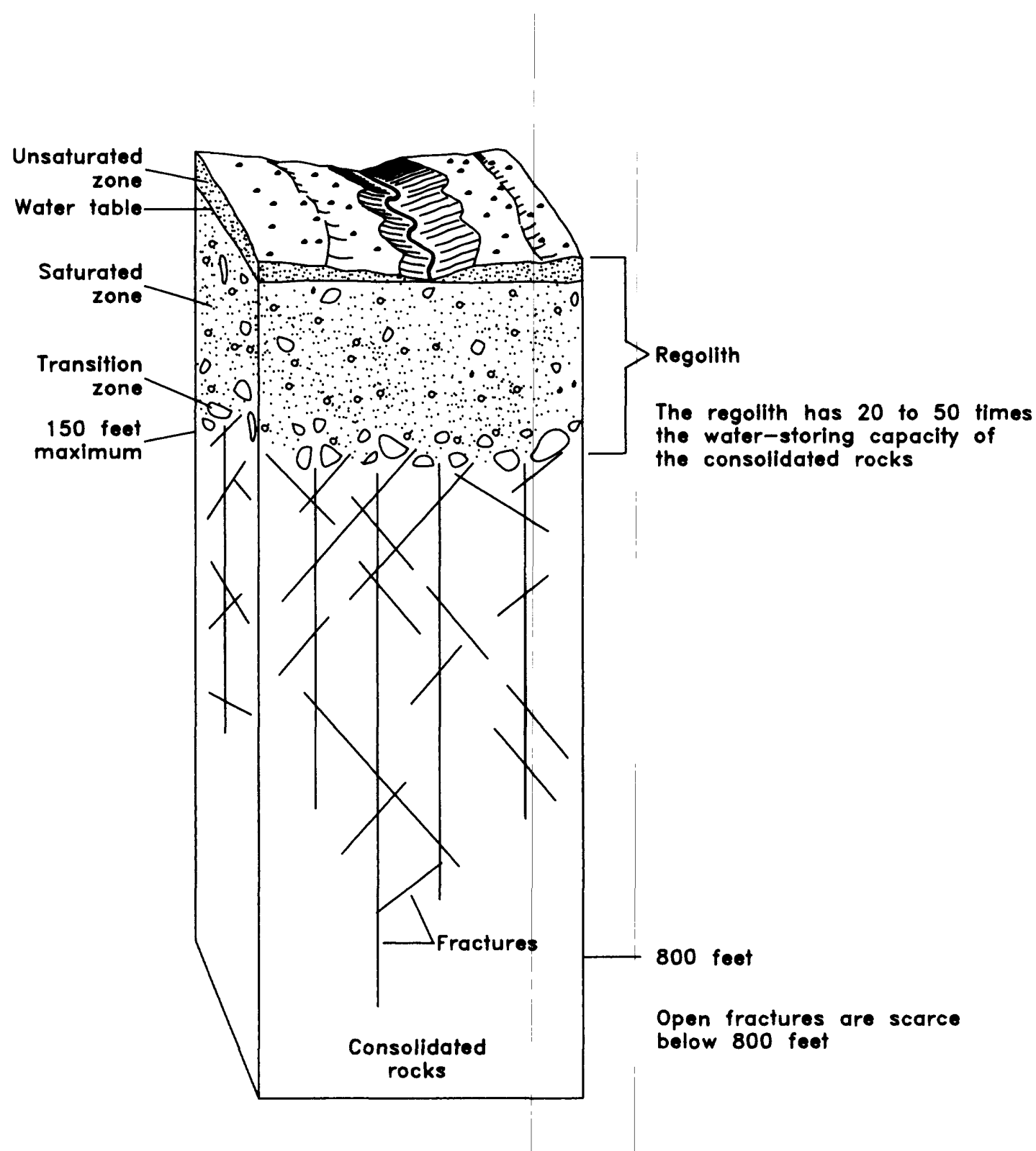

Figure 10.--Principal components of the ground-water system in the Piedmont and Blue Ridge physiographic provinces. (Modified from Heath, 1984, fig. 3.) 
permeability in rocks and increase permeability parallel to these features and reduce permeability at right angles to these features.

\section{Sedimentary-rock regimes}

Ground water in sedimentary-rock regimes within early Mesozoic basins is stored and transmitted primarily through a complex network of interconnected openings formed along joints, fractures, faults, and bedding planes. To a lesser extent, water moves through interstitial pore space and locally enlarged solution channels. The intervening unfractured rock typically has a negligible capacity to store and transmit water. The primary porosity that originally existed in the rocks has commonly been reduced by compaction and cementation. The interconnected openings generally decrease in size and number with increasing depth below land surface. In the Newark basin, for example, a drill hole that has not successfully tapped a water-yielding zone in the first $500 \mathrm{ft}$ of drilling is not likely to penetrate water-yielding zones if drilling is continued. However, in the Culpeper basin of Virginia, at least one public-supply well has produced water at a depth of more than $800 \mathrm{ft}$ (Nelms, D.L., U.S. Geological Survey, oral commun., 1990). Well yields tend to decrease substantially from north to south along this band of sedimentary basins; in fact, yields of wells tapping the rocks of the Wadesboro, Sanford, and Durham basins in North Carolina and South Carolina (fig. 7) are among the lowest in the Piedmont.

Some preferential alignment is typical of secondary openings in consolidated-rock aquifers of the early Mesozoic basins; thus, the aquifers are anisotropic to some degree. In wells open to the Brunswick Group in the Newark basin, drawdown was noted in an observation well $2,400 \mathrm{ft}$ from a pumped well in a direction parallel to the strike of the formation beds, whereas no drawdown was evident in observation wells $600 \mathrm{ft}$ from a pumped well in a direction perpendicular to the strike (Herpers and Barksdale, 1951). Similar observations of the anisotropy of the Brunswick Group have been documented by Vecchioli (1965) and Vecchioli and others (1962).

Preferential flow along strike is probably caused by variable degrees of fracturing in dipping beds. In a highly fractured bed, horizontal flow in the direction of strike is not impeded by boundaries, but horizontal flow in the direction of dip is bounded by adjacent, relatively unfractured beds and by the closure of fractures at depth.

The most productive water-yielding zones in the sedimentary-rock regimes are in fractured red shale, sandstone, and conglomerate. Locally, fractured-shale and sandstone aquifers yield as much as $1,500 \mathrm{gal} / \mathrm{min}$ (Carswell and Rooney, 1976; Nemickas, 1976). Black mudstones, basaltic rocks, diabase, and thermally metamorphosed rocks in the sedimentary basins commonly yield little water. These hydrogeologic units are tapped primarily for domestic supplies, and well yields generally are less than $5 \mathrm{gal} / \mathrm{min}$.

\section{Hydrogeologic Terranes and Conceptual Ground-Water-Flow Systems}

The hydrogeological terranes identified for the Piedmont and Blue Ridge physiographic provinces in the study area are described in table 3 and are further described below. The hydrogeologic terranes associated with local or shallow flow systems are (1) massive or foliated crystalline rocks mantled by thick regolith; (2) massive or foliated crystalline rocks mantled by thin regolith; (3) metamorphosed carbonate rocks; and (4) sedimentary basins.

\section{Massive or foliated crystalline rocks mantled by thick regolith}

Although most wells in the Piedmont and Blue Ridge provinces are open to fractured crystalline rocks, storage characteristics of the overlying regolith probably control the quantity 
of water available to wells (fig. 11). The thickness of the regolith which typically overlies crystalline rocks is highly variable and ranges from 0 to more than $150 \mathrm{ft}$. As defined for this study, "thick regolith" is that which is greater than $50 \mathrm{ft}$. The water yielding capacity of the rocks in this hydrogeologic terrane is greatly dependent upon not only the regolith thickness but also the density, width, and spacing of the fractures in the crystalline rocks.

This hydrogeologic terrane has the highest "average" water yielding capability for the Piedmont and Blue Ridge physiographic provinces. Others however, may have much higher extremes where large dissolution cavities or bottom-hole stress relief fractures exist.

\section{Massive or foliated crystalline rocks mantled by thin regolith}

Massive crystalline rocks that are fractured can be locally significant sources of ground water. Storage within the fractures is generally small. Yields of wells open to massive unmantled, fractured rocks must be sustained by an extensive fracture network connected to a surface-water body; otherwise the well yields will usually be small. In areas of North Carolina, porosities of 1 to 3 percent are common for the fractured rocks (Daniel and Sharpless, 1983).

The stress-relief bottom-of-well fracture system with yields up to $470 \mathrm{gal} / \mathrm{min}$ in the massive crystalline rocks near Atlanta (Cressler and others, 1983) is one example of exceptionally high yields which can occur in this hydrogeologic terrane even without any connection to a surface-water body.

Foliated crystalline rocks generally are anisotropic in terms of physical properties such as orientation of fractures and primary permeability. Fractures are typically at high angles to bedding and foliation because of compressive forces. In the eastern and southeastern United States, compressive forces were oriented gener- ally northwest to southeast. Foliated rocks contain minerals such as mica and chlorite that have laminated-type cleavage planes and that are able to withstand extreme folding and deformation without creating any major secondary permeability. As a result, wells completed in foliated crystalline or highly schistose rocks generally yield only small amounts of water.

\section{Metamorphosed carbonate rocks}

Ground-water flow within metamorphosed carbonate rocks can be significant. McGreevey and Sloto (1976, 1977) reported well yields ranging from 74 to $1,800 \mathrm{gal} / \mathrm{min}$ from the Cockeysville Marble units in eastern Pennsylvania. Solution cavities were reported in metamorphosed carbonate rock in outcrop areas; therefore, secondary permeability is probably significant in these rocks. Yield from the Sylacauga Marble Member of the Talladega Slate in Talladega County, Alabama, was over $900 \mathrm{gal} / \mathrm{min}$ during testing in 1954. One well in that area yielded $700 \mathrm{gal} / \mathrm{min}$ with only $12 \mathrm{ft}$ of drawdown after 3 months of pumping (Causey, 1965).

\section{Sedimentary basins}

Sedimentary basins containing rocks of Mesozoic age (fig. 7) generally are filled with deposits that contain locally significant aquifers, particularly in the northern part of the study area. In places, the sediments filling these basins have been intruded by diabase dikes and sills. Greater than 10 percent of the ground water pumped within the study area during 1985 was from the Newark basin (see basin 15, fig. 7).

The highest yielding wells are largediameter (10 in. or more), relatively deep (200to 600 -ft-deep) wells used for public supply and industry. Yields of $500 \mathrm{gal} / \mathrm{min}$ from these wells are common. Lowest yielding wells are small-diameter (6 in. or less) domestic wells, which are generally less than $250 \mathrm{ft}$ deep. 


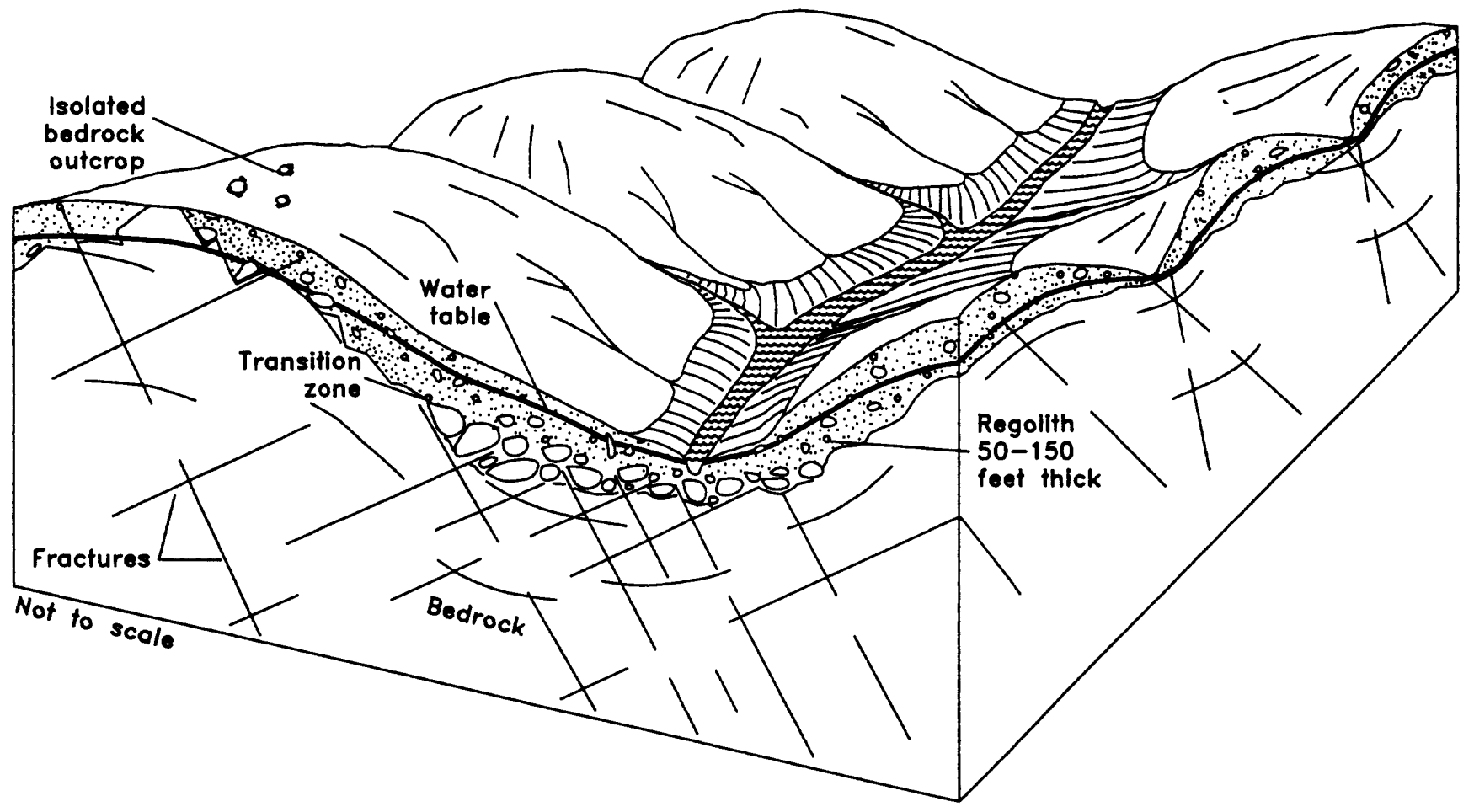

Figure 11.--Hydrogeologic terrane of massive or foliated crystalline rock mantled by thick regolith in the Piedmont or Blue Ridge physiographic provinces. (Modified from Heath, 1984, fig. 36.) 
Yields of 10 to $20 \mathrm{gal} / \mathrm{min}$ from these wells are common.

\section{Ground-Water Quality}

The quality of ground water in the crystalline-rock regimes of the Piedmont and Blue Ridge physiographic provinces generally is suitable for drinking and most other purposes. Mineral composition of the regolith and bedrock strongly affect the quality of the ground water. Water from most light-colored, felsic crystalline metamorphic and igneous rocks is soft (less than $60 \mathrm{mg} / \mathrm{L}$ of hardness) and slightly acidic $(\mathrm{pH}$ less than 7.0) and contains low concentrations of dissolved solids (Powell and Abe, 1985). Water moving through these silica-rich rocks remains relatively dilute because of the chemically resistant nature of the silicate minerals. Water from the dark-colored, mafic crystalline metamorphic and igneous rocks is hard and somewhat alkaline and contains moderate concentrations of dissolved solids as a result of the solubility of calcium- and magnesium-bearing minerals in these rocks. Corrosion of pipes and plumbing fixtures and objectionable concentrations of iron and manganese are the most common water-quality problems.

Water from wells in the sedimentary rocks in the Mesozoic basins generally is hard (greater than $120 \mathrm{mg} / \mathrm{L}$ of hardness as calcium carbonate) to very hard (greater than $180 \mathrm{mg} / \mathrm{L}$ of hardness as calcium carbonate) and somewhat alkaline and contains moderate concentrations of dissolved solids. High concentrations of sulfate (greater than $250 \mathrm{mg} / \mathrm{L}$ ) are a common problem with water from deep wells and directly correspond to high concentrations of dissolved solids. As in crystalline rocks, ground water in sedimentary rocks contains objectionable concentrations of iron and manganese in places. The concentrations of dissolved solids and sulfate increase more with well depth in siltstone than gypsum and pyrite.

The depth of effective circulation of water in the early Mesozoic basins is not known, but depth to the base of potable water appears to be between 1,000 and 2,000 ft in the north (Wood and Wood, 1982) and shallower southward. Few chemical data are available for water from deep aquifers. Most water samples have been taken from discharge points at the tops of wells and represent mixtures of water from all contributing aquifers. Water type is variable with depth. Although calcium magnesium sodium bicarbonate-type water is commonly produced at shallow depths, a calcium magnesium sodium sulfate type or calcium sulfate type is produced at moderate depth and a sodium chloride type is produced from deep aquifers.

In the early Mesozoic basins, there are regional differences in concentrations of the major cations and anions in potable water (Wood and Wood, 1982). The calcium magnesium bicarbonate sulfate facies dominates in basins north of Culpeper, Va., except in Maryland, where the calcium bicarbonate facies dominates. In North Carolina sulfate generally is absent, and water is mostly a sodium calcium magnesium bicarbonate type and rarely is a calcium chloride type. Sodium chloride-type waters apparently dominate at depth in all basins. The regional differences in water chemistry may reflect the regional differences in the mineralogy of the source rocks or the areal variability in depositional environments.

\section{GROUND-WATER ISSUES AND PROBLEMS}

The diversity of ground-water flow conditions in the Valley and Ridge physiographic province and in the Piedmont and Blue Ridge physiographic provinces accounts for the greatly different ground-water issues and problems which exist within these two study areas.

\section{VALLEY AND RIDGE PHYSIOGRAPHIC PROVINCE}

Large ground-water supplies in the Valley and Ridge physiographic province are difficult to locate and develop for several reasons. The 
most productive areas within a carbonate rock aquifer are where the rock has been dissolved to produce sheetlike openings and conduits below the water table (Moore, 1973). The location and extent of these areas appear to be controlled not by lithology alone but by a combination of lithology, geologic structure, topography, and degree of weathering. As a consequence, the most productive areas of the aquifer may underlie less than one-third of its outcrop area (Bradfield, A.D., U.S. Geological Survey, written commun., 1990; Webster, D.A., U.S. Geological Survey, written commun., 1990). In addition, permeability is likely to range through several orders of magnitude within these areas.

Management of ground-water supplies also is difficult because the most permeable parts of the aquifer are shallow and unconfined and therefore are vulnerable to contamination from numerous human activities at land surface. In addition, the aquifers are hydraulically connected to streams, and excessive pumping of wells could induce infiltration from streams or reduce ground-water discharge to streams and thus reduce streamflow by an unacceptable amount.

Specific problems listed below relate to ground-water development and management and examples of each within the Valley and Ridge physiographic province.

Well yields are extremely variable, even from wells tapping the same hydrogeologic units. For example, the range in reported specific capacities of wells in the Conestoga Limestone in south-central Pennsylvania spans four orders of magnitude (fig. 12).

- Sinkholes form during well drilling or pumping. At Erwin, Tenn., more than a dozen sinkholes opened within a few hundred feet of a housing development during exploratory drilling. Similarly, municipal buildings in Rossville, Ga., were threatened by sinkhole formation during well drilling and development nearby (Newton, 1987).

Streamflow is reduced by ground-water withdrawal. Pumping of ground water near Allentown, $\mathrm{Pa}$, resulted in a 39percent reduction in the average annual discharge of nearby Saucon Creek (Wood and others, 1972). In this case, the pumping was related to zinc mining.

Sustainable yield of aquifers is difficult to determine. Although permeability due to solution openings within carbonate rocks can be sufficient to allow pumping of large amounts of water from wells, it is difficult to determine whether an aquifer contains sufficient water in storage to supply the wells during periods of limited recharge. Data are not readily available to estimate aquifer boundaries and storage coefficients; both types of information are needed to determine the volume of water in storage.

Recharge areas are not well defined or protected from contamination. In springdrainage basins underlain by carbonate rock that has undergone dissolution, ground-water flow velocities are sufficiently high that entire basins can be considered vulnerable to contamination.

Water-quality problems resulting from natural geochemical processes include-

- Saline water in shallow wells (100 to $200 \mathrm{ft}$ deep), such as wells in Snyder and Union Counties, central Pennsylvania (Wood, C.R., U.S. Geological Survey, oral commun., 1988) and in the Williamsport, $\mathrm{Pa}$. area (Lloyd and Carswell, 1981). These wells are reported to produce from the Salina Formation which contains evaporites.

- Objectionable concentrations of iron, manganese, and hydrogen sulfide in water from wells completed in shale and in clay-rich carbonate rocks in 


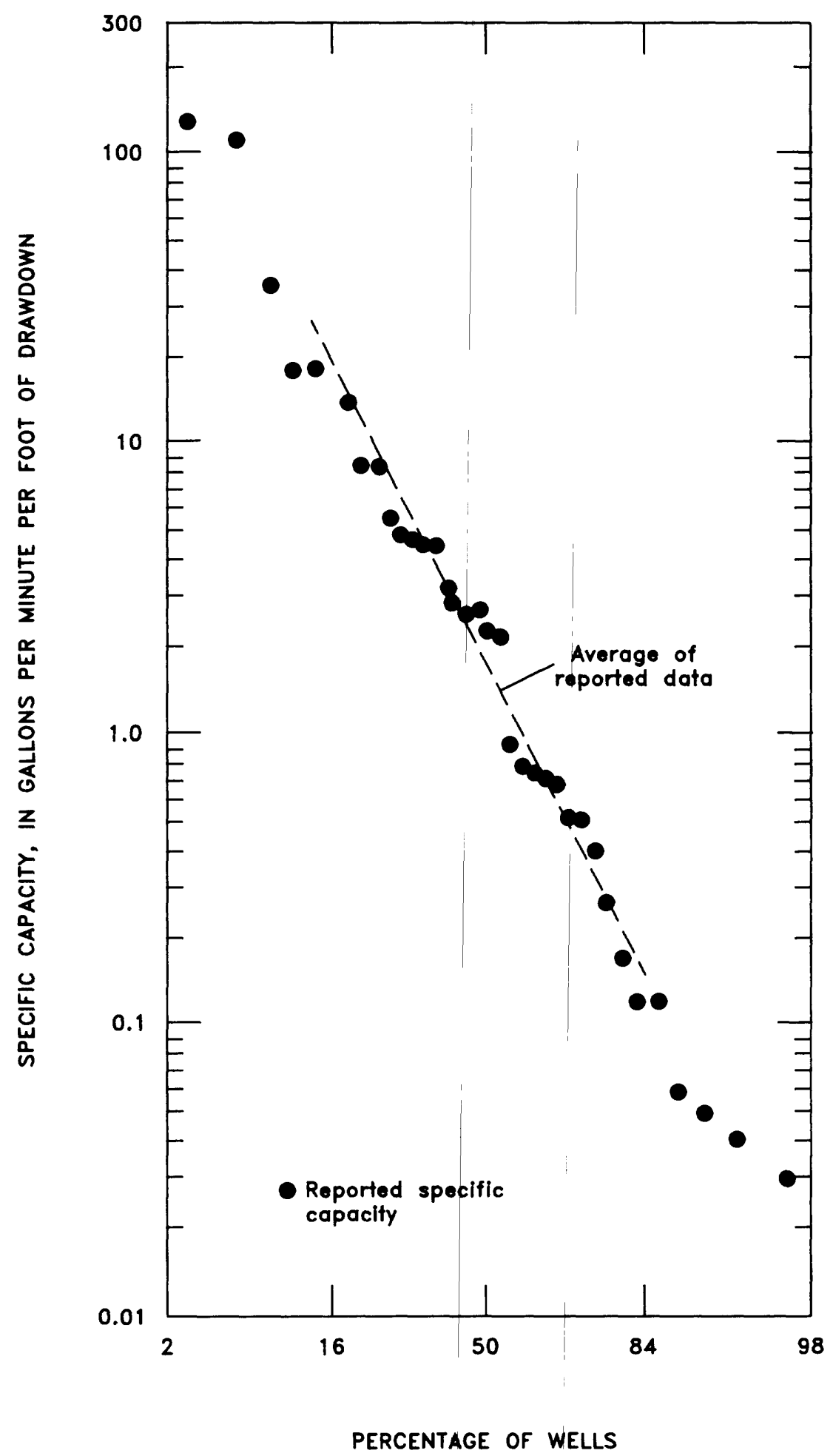

Figure 12.--Cumulative frequency distribution of specific capacity of 35 wells in the Conestoga Limestone, south-central Pennsylvania. (Modified from Seaber and others, 1988, fig. 2.) 
Cumberland County, Pa. (Becher and Root, 1981).

Objectionable concentrations of these constituents are common throughout the Valley and Ridge physiographic province.

Water-quality problems resulting from human activities include-

- Reported moderate concentrations of nitrate $(4 \mathrm{mg} / \mathrm{L}$ as nitrogen) in most samples of water from wells in Cumberland County, $\mathrm{Pa}$. and Clarke County, Va. Increasing nitrate concentration indicate a growing problem of groundwater contamination due to agricultural practices in rural areas underlain by carbonate rocks (Becher and Root, 1981; Wright, 1990).

- Contamination by organic chemicals. Organic contaminants have been detected in the ground water under Anniston Ordinance Depot, which may be within the subsurface drainage basin of Coldwater Spring, the second largest spring in Alabama (Scott, J.C., U.S. Geological Survey, oral commun., 1988). Elsewhere a total of 219,000 gal of gasoline was pumped from ground water and openings in carbonate rock east of Mechanicsburg, $\mathrm{Pa}$. (Becher and Root, 1981).

- Contamination of ground water and surface water due to well drilling. For example, a well being drilled to test for oil and gas lost drilling-fluid circulation at a depth of $1,100 \mathrm{ft}$, presumably in a solution opening in carbonate rock in Craig County, Virginia. Attempts to stop the lost circulation by injection of plugging material caused fish to be killed at a spring several miles away. The spring was the prime source of water for a government fish hatchery
(Wright, W.G., U.S. Geological Survey, written commun., 1988).

○ Use of sinkholes by rural landowners for the disposal of solid and liquid wastes. Numerous cases of contamination of stock and domestic water supplies resulting from this traditional method of waste disposal are on record in State-agency files (Clifford Boles, Tennessee Department of Health and Environment, written commun., 1980).

\section{PIEDMONT AND BLUE RIDGE PHYSIOGRAPHIC PROVINCES}

Although crystalline rocks in the Piedmont and Blue Ridge physiographic provinces have been described as yielding only small quantities of ground water to wells, this description is based upon large numbers of low-yield wells drilled for domestic supplies. These low-yield wells do not represent efforts to obtain quantities of water beyond the minimum requirement of 2 to $10 \mathrm{gal} / \mathrm{min}$ necessary for most households. More than two-thirds of all wells drilled in the Piedmont and Blue Ridge physiographic provinces are used for domestic supply (Mann, 1978; Daniel, 1987). Homeowners have little incentive to pay for additional well footage once a supply of water adequate for their needs has been obtained. Therefore, the yield to a well drilled for a domestic supply almost never is an indication of the full aquifer potential at that site. If many of these domestic wells were drilled deeper, it is probable that additional water-producing fractures within an aquifer would be intersected. In addition, most homes and their wells are located on ridges, hilltops, or slopes which are the least favorable areas for obtaining large yields of ground water (Daniel, 1987). Because of the generally low reported yields and previously abundant surface water, many water-resources planners and managers have not considered ground water as a practical source for large water supplies in the Piedmont and Blue Ridge physiographic provinces. 
A significant number of wells in the Piedmont and Blue Ridge physiographic provinces, however, yield a few tens to a few hundreds of gallons per minute of water. Most of these wells were sited and drilled without regard to geology, topography, and optimal well designs. It is likely that additional high-yield wells can be developed at carefully selected sites.

Results of studies in several areas of the Piedmont physiographic province show that the aquifers can provide large amounts of water to wells. Daniel and Sharpless (1983) list more than 300 wells in an 8-county area of central North Carolina that produced $50 \mathrm{gal} / \mathrm{min}$ or more of water. Cressler and others (1983) report that a significant number of wells in the Piedmont physiographic province in Georgia yielded more than $100 \mathrm{gal} / \mathrm{min}$ and that some wells yielded nearly $500 \mathrm{gal} / \mathrm{min}$. They also identify 66 wells used primarily for industrial and municipal supplies that had been in use for periods of 12 to more than 30 years without declines in yield. Similarly, Cederstrom (1972) reports that well yields of 100 to $300 \mathrm{gal} / \mathrm{min}$ were common for bedrock wells in the Piedmont and Blue Ridge physiographic provinces from Maine to Virginia.

Increasing population growth, industrial development, and recent droughts have increased the demand for additional water supplies in the study area, especially in the northern basins. Increased ground-water pumpage has caused significant declines in water levels in places; decreases in well yields; interference between closely spaced wells; and, possibly, a decrease of ground-water discharge to streams and a resulting decrease in base flow.

Water-quality problems from natural geochemical processes result from-

- The mineral composition of the rocks;

- Seasonal variation in recharge;

- Duration of water-rock contact; and
- Presence of radon, radium, and uranium in the rocks and soils.

Of all the natural constituents in ground water, radionuclides potentially pose the greatest threat to human health in the Piedmont and Blue Ridge physiographic provinces. Since 1984, indoor radon gas has gained National attention as a major cause of lung cancer in the United States. The crystalline rocks of the Piedmont consist in part of granite and gneiss that contain small to moderate amounts of uranium, which is a source of radon gas; the amounts are sufficient for radon to eminate significantly from the regolith and the part of the underlying fractured rock above the water table (LeGrand, 1987). One of the pathways for radon gas migration into households is through ground water and aeration of the water at faucets and showerheads. In addition to radon, high concentrations of dissolved radium and uranium nuclides have been detected in ground-water supplies tapping crystalline and sedimentary rocks of the Piedmont physiographic province (Zapecza and Szabo, 1988). High concentrations of radium and uranium in drinking water are known to be carcinogenic.

Water-quality problems resulting from human activity include-

- Discharge from septic tanks;

- leaking gasoline from storage tanks;

- improper handling and/or transport of industrial chemicals;

- improperly constructed water wells;

- agricultural activities (application of pesticides and fertilizers, and feedlot and barnyard wastes);

- highway de-icing salts; and

- infiltration of contaminated surface water from lakes and streams. 


\section{PLAN OF STUDY}

Understanding and quantifying the diverse, complex hydrogeologic environment of the APRASA study area is difficult because the aquifers are discontinuous, independent, and contain mostly secondary permeability. The first step, in this study required the development of a list of well-defined, attainable objectives. The methods to attain these objectives requires using both a geographic information system (GIS) and models of individual basins representing each of the hydrogeologic terranes. The abundant hydrogeologic and water-quality data must be collected, collated, and synthesized for analysis. Finally, report products must be specified early in the project to give definitive direction for the project goals.

\section{OBJECTIVES}

General objectives of the U.S. Geological Survey's RASA studies are described by Sun (1986). Specific objectives of the APRASA are as follows:

1. Define the hydrogeologic framework of each of the physiographic provinces according to how lithology, structure, topography, or other relevant features are related to the hydraulic properties of the rocks. Then, define the major hydrogeologic terranes within each of the physiographic provinces.

2. Delineate and describe quantitatively the major hydrologic processes that affect ground-water quantity and quality within the three physiographic provinces.

3. Quantify the components of ground-water flow systems in typical areas within the hydrogeologic terranes. Identify the hydrologic factors controlling recharge and discharge. Assess the response of hydrogeologic terranes to ground-water development.
4. Provide regional estimates of the groundwater budget, including pumpage, natural discharge, recharge, and aquifer storage.

5. Determine the relation between surfacewater and ground-water-flow systems and their effects on availability and quality of ground water.

6. Describe the ground-water quality for the study area by physiographic province and by hydrogeologic terrane, where possible.

7. Develop a data base to aid in planning, development, and management of groundwater resources in the three physiographic provinces.

Attainment of these specific objectives will assist water-resource planners and managers in developing potential water supplies and meeting the increasing demands on existing sources of water in the study area. In addition, data and information gathered during this study could be applied to similar hydrologic settings.

\section{APPROACH}

The fundamental approach of this study will be similar to that of other RASA studiesthat is, available geologic and hydrologic data will be assembled and used to describe aquifer systems. In the APRASA study, however, the diverse nature and the lack of regional continuity of aquifers prevent the development of a regional ground-water-flow model for the entire study area.

Definition of the hydrogeologic framework and delineation of the major processes affecting ground-water flow and development within the study area require knowledge of:

1. The types of rocks within which water resides or through which ground water flows;

2. The expected yields to wells in each of the aquifers; 
3. The quantities of natural recharge and discharge from the ground-water system;

4. The topographic location (hilltops, slopes, valleys) of wells;

5. Well-construction and well-development practices and their effects on yields in the area;

\section{Water-level information;}

7. Transmissivity or hydraulic-conductivity information;

8. Aquifer boundaries for the study area and hydrogeologic terranes; and

9. The thickness of the freshwater system.

The two specific approaches to be used in achieving the first two objectives for this project will probably overlap to some extent. The first approach is based on full-scale implementation and use of a GIS for the entire study area. Previously mapped geologic contacts and structure for those parts of the 11 states within the APRASA area will be digitized and the GIS will be used to assign lithologic information to each of the polygon areas of the digitized map. Then, by combining areas or formations of similar lithology, the initial number of polygons can be reduced. A further reduction in the number of polygons can be achieved by combining lithologies that have similar hydrologic characteristics; for example, granite, granodiorite, and quartz monzonite could be combined into a single class called felsic intrusives. Several different types of lithologic aggregations will be attempted to create categories that will represent hydrologic uniformity without sacrificing the independent character of each lithologic type. The initial products of this digitizing effort and combining of similar units will be preliminary maps of hydrogeologic units or terranes in the study area. These hydrogeologic-terrane maps will continually be revised during the course of the APRASA study as additional information is collected on each area and lithology.
Further refinement of the initial hydrogeologic-terrane maps will be made as well-yield data (specific-capacity or aquifer-test data) are compared with the GIS coverages. As additional digital coverages such as precipitation, rainfall-runoff, stream discharge and low-flow discharge, ground-water and surfacewater quality, and land-surface elevation-are integrated with the preliminary hydrogeologicterrane maps, the areas of specific ground-water characteristics will be improved.

A subproject to determine what factors control the well-yield potential of rocks within the study area was done early in this study (Knopman, D.S., 1991). Through a statistical analysis of the extensive well information in the Ground-Water Site Information (GWSI) files of the U.S. Geological Survey in Pennsylvania, it was shown that perhaps as much as 54 percent of the variability in well yields can be accounted for by characteristics such as water use, casing diameter, well depth, regolith thickness, topographic setting, and aquifer lithology. Although "water use" is not a determinant of hydrologic characteristics, this category in GWSI could prove useful as an indicator of optimum yield of wells in certain aquifers. Wells developed for public supply, for example, are usually more thoroughly developed, of larger diameter, drilled deeper, and fitted with more powerful pumps than are wells for domestic supplies.

The second specific approach for achieving the first two objectives (framework and processes) of this study requires quantification of the ground-water-flow characteristics within selected "type areas" that are representative of flow in the hydrogeologic terranes. In this effort, a flow system will be conceptualized for each hydrogeologic terrane, and significantly different ground-water-flow regimes in these type areas will be simulated by use of numerical methods. Most flow will be simulated as a hydraulic continuum (if Darcy's Law applies) by use of the finite-difference method. Other models, such as turbulent "pipe flow" models, may be required for flow systems that are not adequately described by Darcy's Law. It may 
be necessary, for example, to employ a model that couples hydraulic-continuum flow for areas where flow is diffuse with turbulent pipe flow for zones of concentrated flow near springs. Other numerical methods, such as the finiteelement method, may be required because of complex geometry of some flow systems. These models will improve the understanding of the role that individual hydrogeologic components have on each flow system. The knowledge gained will be transferable to other areas within the same hydrogeologic terrane. Small type-area studies will be chosen to represent flow in a specific hydrogeologic terrane; however, it is recognized that a particular type area could encompass a flow system that is hydraulically interconnected with more than one hydrogeologic terrane. Studies of type areas for the most commonly existing flow systems will provide techniques needed to quantify recharge, discharge, storage, and flow on a regional basis.

The type-area studies will be conducted by USGS District-level personnel and will be selected on the basis of (1) the hydrogeological significance of systems within each physiographic province, (2) the sufficiency of available data for quantification of the ground-water-flow systems, (3) the backgrounds of the proposed investigators, and (4) the technical soundness of the proposals. It is estimated that two or three type-area studies will be done for the Valley and Ridge physiographic province and an additional two or three type-area studies will be done for the Piedmont and Blue Ridge physiographic provinces. As these type-area studies are completed, analyses and statistical tests will be done to determine the transferability of the information gained from each study to other areas within the same hydrogeologic terrane.

Where information on ground-water chemistry is available for type areas, speciation or flow-path precipitation-solution modeling will be done to refine further the understanding of dissolution, time of travel, and depth of circulation for flow within these specific areas.
The approach for estimating the regional ground-water budget (objective 4) and determining the hydrologic factors controlling recharge and discharge (objective 5) will be to analyze the relation between ground water and surface water in approximately 200 basins in the study area. Base flow will be analyzed to identify and quantify the ground-water contributions to streamflow, provide estimates of natural recharge and evapotranspiration, and provide estimates of aquifer diffusivity (transmissivity divided by storage coefficient). Streamdischarge and low-flow data will be digitized on a point basis into a GIS coverage file and will be compared with other digitized data.

Water-chemistry data from each state within the study area will be acquired and evaluated for accuracy as a first step toward describing the natural ground-water quality for the APRASA study area (objective 6). By means of trilinear plots of major constituents, pie diagrams, and other methods to statistically present this data for the study area as a whole, the chemical character of ground water and surface water will be indicated on maps for each of the physiographic provinces. Where data are available, the chemical character of ground water will also be described for the major hydrogeologic terranes. Chemical analyses done as part of the type-area projects will expand upon the regional representation of water quality through intensive sampling in a small area. If sufficient data are available for certain areas, temporal changes of water quality will be noted and explained. Currently (June 1990), the water-quality files obtained from the USGS offices in each state consist of 200,000 separate analyses for ground water and surface water. Data for as many as 277 constituents could be included for some of the analyses.

Regional data bases containing geologic, hydrologic, water-quality, climatic, precipitation, runoff, population, pumpage, and streamflow information will be compiled. These data will be collected from existing USGS files, published reports, and files of other Federal and State agencies. In addition, some 
data may be obtained from private industrial sources. All data will be reformatted into machine-readable files, and selected data types will be statistically analyzed by use of multivariant factor analysis to identify significant trends of multiple variables and the effect of the individual components on the water-yielding potential of different hydrogeologic terranes.

The initial ground-water data base compilation includes almost 50,000 separate well entries in the computer files of the 11 states within the study area. Of the initial well data obtained, almost one-half are for sites within Pennsylvania. Data for fewer than 3,000 sites are available for many of the states, and data are limited to fewer than 1,000 sites for some states. Efforts to obtain additional data on wells have been ongoing in USGS offices in each state since the beginning of this study. In some states, extensive additional information has been obtained. Despite the additional data available for wells, however, there is a paucity of data on well yields, and specific-capacity data are particularly scarce. For some states, specific-capacity data are available for fewer than 10 sites. Specific capacity has been selected as an important factor for assessment of aquifer properties because specific capacity, unlike reported well yield, is directly related to the transmissivity of the aquifer.

As a result of the scarce specific-capacity data, a study to seek a surrogate or surrogates for specific capacity was begun in 1989 based on information in the Pennsylvania data base for both the Valley and Ridge physiographic province and the Piedmont and Blue Ridge physiographic provinces. Preliminary results indicate that, if drawdown data are not available, there is no useful surrogate for the specific capacity of wells completed in relatively pure limestone and dolomite; however, yield divided by well depth could be useful in predicting the average specific capacity of municipal and industrial wells in all other rock types (Hippe, D.J., U.S. Geological Survey, written commun., 1989).
An additional effort to develop a data file for springs is underway for the Valley and Ridge physiographic province where spring information can be useful in understanding the ground-water-flow systems in some carbonate rocks. Reports for Tennessee (Hollyday and Smith, 1990) and Pennsylvania (Saad and Hippe, 1990) written as part of this study include the locations and discharges of large springs that have been measured within the Valley and Ridge physiographic province.

A schedule of major work elements for the APRASA is shown in figure 13.

\section{ORGANIZATION}

The APRASA study will be directed by a central staff in Richmond, Va. The staff will consist of a project leader and three hydrologists specializing in some combination of data-base administration, geology, geochemistry, groundwater and surface-water interactions, and numerical flow simulation.

The study area is divided into two subregions, the Valley and Ridge physiographic province and the Piedmont and Blue Ridge physiographic provinces. One subregional project leader will be designated as chief for each of the subregional areas. Each chief will be responsible for defining the hydrogeologic framework and factors affecting flow in hydrogeologic terranes within his study area. Individual District offices within the project area will collect and compile data and enter these data into computer files. The project staff will provide the Districts with descriptions of the hydrogeologic terranes and will formulate concepts of flow within these terranes and the criteria for selecting type areas within which to test these concepts of flow. The Districts will propose suitable type areas and, under supervision of the project staff, will conduct quantitative studies of ground-water flow in the type areas selected and funded by the project. 


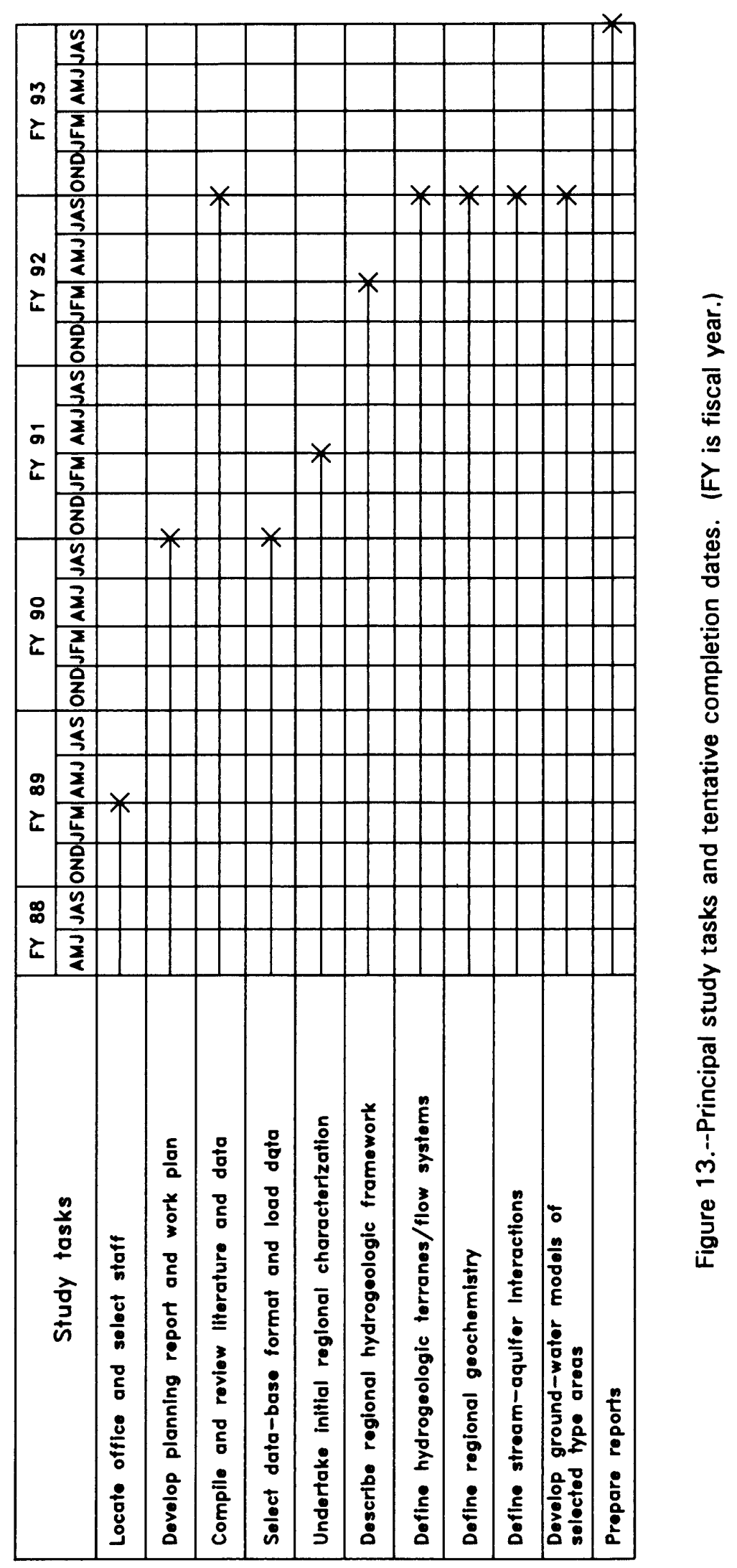




\section{PROPOSED REPORTS}

The findings of the APRASA will be presented in a series of chapters of a USGS Professional Paper prepared at the conclusion of the study. Many interim reports presenting the data, methods, and preliminary findings and conclusions are planned to be written while the study is in progress. These reports will be released as USGS Open-File Reports, USGS Water-Resources Investigations Reports, or journal articles. Most of the early reports will be map-type reports covering such subjects as-

1. Hydrogeologic terranes for the study area within groups of states,

2. Surface-water and ground-water interactions,

3. Trends in water use and population,

4. Thickness of weathered zone (inferred from reported length of well casings) for specific areas,

5. Well yields,

6. Areal differences in water quality,

7. Hydrogeologic characteristics, boundaries, and hydraulic properties of type areas,

8. Springs in the Valley and Ridge physiographic province,

9. Statistical analysis of factors controlling the water-yielding potential of rocks,
10. Hydrogeologic factors controlling specific capacity, and

11. Preliminary simulations of ground-water flow in the type areas.

The Professional Paper will consist of the following seven chapters:

A. Summary of the Regional Aquifer System Analysis of the Appalachian Valley and Ridge, Piedmont, and Blue Ridge Physiographic Provinces of the Eastern and Southeastern United States.

B. Hydrogeologic framework of the Piedmont and Blue Ridge Physiographic Provinces.

C. Hydrogeologic framework of the Appalachian Valley and Ridge Physiographic Province.

D. Geochemistry of ground water in the Appalachian Valley and Ridge, Piedmont, and Blue Ridge Physiographic Provinces.

E. Hydrogeology and digital model analysis of representative areas in the Piedmont and Blue Ridge Physiographic Provinces.

F. Hydrogeology and digital model analysis of representatives areas in the Appalachian Valley and Ridge Physiographic Province.

G. Analysis of ground-water and surfacewater interactions for the Appalachian Valley and Ridge, Piedmont, and Blue Ridge Physiographic Provinces. 


\section{SELECTED REFERENCES}

Adams, G.I., Butts, Charles, Stevenson, L.W., and Cooke, C.W., 1926, Geology of Alabama: Geological Survey of Alabama Special Report $14,312 \mathrm{p}$.

Becher, A.E., and Root, S.I., 1981, Ground water and geology of the Cumberland Valley, Cumberland County, Pennsylvania: Pennsylvania Geological Survey, 4th Series, Water Resource Report W-50, 95 p.

Becher, A.E., and Taylor, L.E., 1982, Groundwater resources in the Cumberland and contiguous valleys of Franklin County, Pennsylvania: Pennsylvania Geological Survey, 4th Series, Water Resource Report W-53, 67 p.

Bennison, A.P., 1975, Geological highway map of the southeastern region: American Association of Petroleum Geologists, United States Geological Highway Map 9, scale $1: 1,900,000$.

1976, Geological highway map of the northeastern region: American Association of Petroleum Geologists, United States Geological Highway Map 10, scale 1:1,900,000.

Brahana, J.V., Bradley, M.W., and Macy, J.A., 1986, Delineation and description of the regional aquifers of Tennessee-The East Tennessee aquifer system: U.S. Geological Survey Water-Resources Investigations Report 82-4091, 30 p.

Brahana, J.V., and Hollyday, E.F., 1988, Dry stream reaches in carbonate terranes-Surface indicators of ground-water reservoirs: American Water Resources Association Bulletin, v. 24., no. 3 , p. 577-580.

Brent, W.B., 1960, Geology and mineral resources of Rockingham County: Virginia Division of Mineral Resources Bulletin 76, 174 p.

Butler, J.R., and Ragland, P.C., 1969, A petrochemical survey of plutonic intrusions in the
Piedmont, Southeastern Appalachians, U.S.A.: Contributions to Mineralogy and Petrology, v. 24 , p. $164-190$.

Cady, R.C., 1936, Ground-water resources of the Shenandoah Valley, Virginia: Virginia Geological Survey Bulletin 45, 137 p.

Carswell, L.D., and Rooney, J.G., 1976, Summary of geology and ground-water resources of Passaic County, New Jersey: U.S. Geological Survey Water-Resources Investigations Report 76-75, $47 \mathrm{p}$.

Causey, L.V., 1965, Availability of ground water in Talladega County, Alabama: Geological Survey of Alabama, Bulletin 81, $63 \mathrm{p}$.

Cederstrom, D.J., 1972, Evaluation of yields of wells in consolidated rocks, Virginia to Maine: U.S. Geological Survey Water-Supply Paper 2021, 38 p.

Christensen, R.C., Faust, R.J., and Harris, W.F., Jr., 1975, Water resources, in Environmental geology and hydrology, Huntsville and Madison County, Alabama: Geological Survey of Alabama Atlas Series 8, p. 40-83.

Collins, W.D., Foster, M.D., Reeves, Frank, and Meacham, R.P., 1930, Springs of Virginia: Virginia Division of Water Resources and Power Bulletin 1, 55 p.

Cooper, B.N., 1966, Geology of the salt and gypsum deposits in the Saltville area, Smyth and Washington Counties, Virginia, in Symposium on Salt, v. 2, pt. 1, Geology, Chemistry, and Mining: Cleveland, Ohio, Northern Ohio Geological Society, p. 11-35.

Cressler, C.W., Thurmond, C.J., and Hester, W.G., 1983, Ground water in the Greater Atlanta Region: Georgia Geologic Survey Information Circular 63, 144 p. 
Daniel, C.C., III, 1987, Statistical analysis relating well yield to construction practices and siting of wells in the Piedmont and Blue Ridge provinces of North Carolina: U.S. Geological Survey Water-Resources Investigations Report 86-4132, 54 p.

Daniel, C.C., III, and Sharpless, N.B., 1983, Ground-water supply potential and procedures for well-site selection in the upper Cape Fear River basin, North Carolina: North Carolina Department of Natural Resources and Community Development, 73 p.

DeBuchananne, G.D., and Richardson, R.M., 1956, Ground-water resources of East Tennessee: Tennessee Division of Geology Bulletin 58, pt. 1, 393 p.

Faulkner, G.L., 1976, Flow analysis of karst systems with well developed underground circulation, in Yevjevich, Vujca, Karst hydrology and water resources-Proceedings of the U.S.-Yugoslavian Symposium, Dubrovnik, Yugoslavia, June 2-7, 1975: Ft. Collins, Colo., Water Resources Publications, v. 1, Karst Hydrology, p. 137-164.

Fenneman, N.M., 1946, Physical divisions of the United States: U.S. Geological Survey map, scale $1: 7,000,000$.

Flippo, H.N., 1974, Springs of Pennsylvania: Pennsylvania Department of Environmental Resources Water Resources Bulletin 10, $46 \mathrm{p}$.

Foxx, Susanne, 1981, A summary of the geohydrology and of the spring recharge zones within the Tennessee portion of the 208 study area of the First Tennessee-Virginia Development District: Tennessee Valley Authority Division of Water Resources report WR28-1-520-116, $54 \mathrm{p}$.

Froelich, A.J., and Olsen, P.E., 1985, Newark Supergroup-A revision of the Newark Group in Eastern North America, in Robison, G.R. and Froelich, A.J., eds., Proceedings of the Second U.S. Geological Survey Workshop on the Early Mesozoic Basins of the Eastern United States: U.S. Geological Survey Circular 946, p. 1-3.

Gebert, W.A., Graczyk, D.J., and Krug, W.R., 1987, Average annual runoff in the United States, 1951-80: U.S. Geological Survey Hydrologic Investigations Atlas HA-710, scale 1:7,500,000.

Gerhart, J.M., and Lazorchik, G.J., 1988, Evaluation of the ground-water resources of the lower Susquehanna River basin, Pennsylvania and Maryland: U.S. Geological Survey Water-Supply Paper 2284, 128 p.

Heath, R.C., 1984, Ground-water regions of the United States: U.S. Geological Survey WaterSupply Paper 2242, 78 p.

Herpers, Henry, and Barksdale, H.C., 1951, Preliminary report on the geology and groundwater supplies of the Newark, New Jersey, area: New Jersey Department of Conservation and Economic Development, Division of Water Policy and Supply, Special Report 10, $52 \mathrm{p}$.

Higgins, M.W., Atkins, R.L., Crawford, T.J., Crawford, R.F., III, Brooks, R., and Cook, R.B., 1988, The structure, stratigraphy, tectonostratigraphy, and evolution of the southernmost part of the Appalachian Orogen: U.S. Geological Survey Professional Paper $1475,173 \mathrm{p}$.

Hinkle, K.R., and Sterrett, R.M., 1976, Rockingham County groundwater: Virginia State Water Control Board Planning Bulletin 300, 88 p.

---- 1978, Groundwater resources of Augusta County, Virginia: Virginia State Water Control Board Planning Bulletin 310, 119 p.

Hobba, W.A., Jr., Fisher, D.W., Pearson, F.J., Jr., and Chemerys, J.C., 1979, Hydrology and geochemistry of thermal springs of the Appalachians: U.S. Geological Survey Professional Paper 1044-E, 36 p. 
Hollyday, E.F., and Goddard, P.L., 1979, Groundwater availability in carbonate rocks of the Dandridge area, Jefferson County, Tennessee: U.S. Geological Survey Open-File Report 79-1263, $50 \mathrm{p}$.

Hollyday, E.F., and Smith, M.A., 1990, Large springs in the Valley and Ridge Province in Tennessee: U.S. Geological Survey WaterResources Investigations Report 89-4295, 9 p.

Johnston, W.D., Jr., 1933, Ground water in the Paleozoic rocks of northern Alabama: Geological Survey of Alabama Special Report 16, pt. 1, 414 p.

King, P.B., 1977, The evolution of North America: Princeton, N.J., Princeton University Press, $197 \mathrm{p}$.

King, P.B., and Beikman, H.M., 1974, Geologic map of the United States: U.S. Geological Survey map, scale 1:2,500,000.

Knopman, D.S., 1991, Factors relating to the wateryielding potential of rocks in the Piedmont and Valley and Ridge provinces of Pennsylvania: U.S. Geological Survey Water-Resources Investigations Report 90-4147, 52 p.

Laczniak, R.J., and Zenone, Chester, 1985, Ground-water resources of the Culpeper basin, Virginia and Maryland: U.S. Geological Survey Miscellaneous Investigations Series Map I-1313-F, scale 1:125,000.

Lattman, L.H., 1958, Technique of mapping geologic fracture traces and lineaments on aerial photographs: Photogrammetric Engineering, v. 24 , no.4, p. $568-576$.

Lattman, L.H., and Parizek, R.R., 1964, Relationship between fracture traces and the occurrence of ground water in carbonate rocks: Journal of Hydrology, v. 2, p. 73-91.

LeGrand, H.E., 1960, Geology and ground-water resources of Pittsylvania and Halifax Counties: Virginia Division of Mineral Resources Bulletin 75, 86 p.
--- 1987, Radon and radium emanations from fractured crystalline rocks-A conceptual hydrogeological model: Ground Water, v. 25, no. 1 , p. 59-69.

Lloyd, O.B., and Carswell, L.D., 1981, Groundwater resources of the Williamsport region, Lycoming County, Pennsylvania: Pennsylvania Geological Survey, 4th Series, Water Resource Report W-51, 69 p.

Lohman, S.W., 1938, Ground water in southcentral Pennsylvania: Pennsylvania Geological Survey, 4th Series, Water Resource Report $\mathrm{W}-5,315 \mathrm{p}$.

Mann, L.T., 1978, Public water supplies of North Carolina-A summary of water resources, use, treatment, and capacity of water-supply systems: U.S. Geological Survey WaterResources Investigations Report 78-16, 61 p.

McGreevy, L.J., and Sloto, R.A., 1976, Selected hydrologic data, Chester County, Pennsylvania: U.S. Geological Survey Open-File Report, 138 p.

---- 1977, Ground water resources of Chester County, Pennsylvania: U.S. Geological Survey Water-Resources Investigations Report 77-67, 76 p.

Meinzer, O.E., 1927, Outline of ground-water hydrology with definitions: U.S. Geological Survey Water-Supply Paper 494, 71 p.

Moore, G.K., 1973, Hydraulics of sheetlike solution cavities: Ground Water, v. 11, no. 4, p. 4-11.

---- 1976, Lineaments on Skylab photographsDetection, mapping, and hydrologic significance in central Tennessee: U.S. Geological Survey Open-File Report 76-196, 81 p.

Mussman, W.J., Montanez, I.P., and Read, J.F., 1988, Ordovician Knox paleokarst unconformity, Appalachians, in James, N.P., and Choquette, P.W., eds., Paleokarst: New York, Springer-Verlag, p. 211-228. 
Nemickas, Bronius, 1976, Geology and groundwater resources of Union County, New Jersey: U.S. Geological Survey WaterResources Investigations 76-73, 103 p.

Newton, J.G., 1987, Development of sinkholes resulting from man's activities in the eastern United States: U.S. Geological Survey Circular $968,54 \mathrm{p}$.

Nutter, L.J., and Otton, E.G., 1969, Ground-water occurrence in the Maryland Piedmont: Maryland Geological Survey Report of Investigations $10,56 \mathrm{p}$.

Olmsted, F.H., and Hely, A.G., 1962, Relations between ground water and surface water in the Brandywine Creek basin, Pennsylvania: U.S. Geological Survey Professional Paper 417-A, $21 \mathrm{p}$.

Osborne, W.E., and Szabo, M.W., 1984, Stratigraphy and structure of the Jacksonville fault, Calhoun County, Alabama: Geological Survey of Alabama Circular 117, $30 \mathrm{p}$.

Overstreet, W.C., and Bell, Henry, III, 1965, The crystalline rocks of South Carolina: U.S. Geological Survey Bulletin 1183, 126 p.

-.- 1965, Geologic map of the crystalline rocks of South Carolina: U.S. Geological Survey Miscellaneous Geologic Investigations Map I-413, 1 sheet.

Parizek, R.R., White, W.B., and Langmuir, Donald, 1971, Hydrogeology and geochemistry of folded and faulted carbonate rocks of the central Appalachian type and related land use problems: Washington, D.C., Geological Society of America and associated societies, $184 \mathrm{p}$.

Posner, Alex, and Zenone, Chester, 1983, Chemical quality of ground water in the Culpeper Basin, Virginia and Maryland: U.S. Geological Survey, Miscellaneous Investigations Series, I-1313-D, 1 plate, scale 1:125,000.
Powell, J.D., and Abe, J.M., 1985, Availability and quality of ground water in the Piedmont province of Virginia: U.S. Geological Survey Water-Resources Investigations Report 85-4235, 33 p.

Rader, E.K., and Gathright, T.M., II, 1984, Stratigraphy and structure in the thermal springs area of the western anticlines: Virginia Division of Mineral Resources, Sixteenth Annual Virginia Geologic Field Conference guidebook, October 13-14, 1984, Charlottesville, $58 \mathrm{p}$.

Ragland, P.C., Hatcher, R.D., Jr., and Whittington, David, 1983, Juxtaposed Mesozoic diabase dike sets from the Carolinas-A preliminary assessment: Geology, v. 11, p. 394-399.

Renfro, H.B., and Feray, D.E., 1970, Geological highway map of the mid-Atlantic region: American Association of Petroleum Geologists, United States Geological Highway Map 4, scale $1: 1,900,000$.

Rorabaugh, M.I., 1964, Estimating changes in bank storage and ground-water contribution to streamflow: International Association of Scientific Hydrology Publication 63, p. $432-441$.

Saad, D.A., and Hippe, D.J., 1990, Large springs in the Valley and Ridge physiographic province of Pennsylvania: U.S. Geological Survey Open-File Report 90-164, 17 p.

Schneider, W.J., Barksdale, H.C., Meyer, Gerald, Friel, E.A., Collier, C.R., Whetstone, G.W., Wark, J.W., Musser, J.J., Wilmoth, B.M., and LeGrand, H.E., 1965, Water resources of the Appalachian region, Pennsylvania to Alabama: U.S. Geological Survey Hydrologic Atlas HA-198, 11 sheets.

Scott, J.C., Harris, W.F., and Cobb, R.H., 1987, Geohydrology and susceptibility of Coldwater Spring and Jacksonville fault areas to surface contamination in Calhoun County, Alabama: U.S. Geological Survey Water-Resources Investigations Report 87-4031, 29 p. 
Seaber, P.R., Brahana, J.V., and Hollyday, E.F., 1988, Region 20, Appalachian Plateaus and Valley and Ridge, in Back, William, Rosenshein, J.S., and Seaber, P.R., eds., Hydrogeology: Boulder, Colo., Geological Society of America, The Geology of North America, v. 0-2, p. 189-200.

Smoot, J.P., and Robinson, G.R., Jr., 1988, Baseand precious-metal occurrence in the Culpeper basin, northern Virginia, in Froelich, A.J., and Robinson, G.R., Jr., eds., Studies of the Early Mesozoic basins of the Eastern United States: U.S. Geological Survey Bulletin 1776, p. 403-423.

Solley, W.B., Merk, C.F., and Pierce, R.R., 1988, Estimated use of water in the United States in 1985: U.S. Geological Survey Circular 1004, $82 \mathrm{p}$.

Stewart, J.W., 1962, Water-yielding potential of weathered crystalline rocks at the Georgia Nuclear Laboratory: U.S. Geological Survey Professional Paper 450-B, p. B106-B107.

Stewart, J.W., Callahan, J.T., Carter, R.F., and others, 1964, Geologic and hydrologic investigation at the site of the Georgia Nuclear Laboratory, Dawson County, Georgia: U.S. Geological Survey Bulletin 1133-F, 90 p.

Sun, R.J., 1986, Regional aquifer-system analysis program of the U.S. Geological Survey-Summary of projects, 1978-84: U.S. Geological Survey Circular 1002, 264 p.

Tilton, G.R., Davis, G.L., and Bass, M.N., 1960, 1000 Million-year-old minerals from the eastern U.S.: Journal of Geophysical Research, v. 65, p. 4173-4179.

Toth, Jozsef, 1963, A theoretical analysis of groundwater flow in small drainage basins: Journal of Geophysical Research, v. 68, p. 4795-4812.

Trainer, F.W., and Watkins, F.A., 1975, Geohydrologic reconnaissance of the Upper
Potomac River basin: U.S. Geological Survey Water-Supply Paper 2035, 68 p.

Tucci, Patrick, 1986, Ground-water flow in Melton Valley, Oak Ridge Reservation, Roane County, Tennessee-Preliminary model analysis: U.S. Geological Survey WaterResources Investigations Report 85-4221, $20 \mathrm{p}$.

U.S. Geological Survey, 1970, The national atlas of the United States of America-Karstlands and Caverns maps: Washington, D.C., U.S. Geological Survey, p 77.

----1985, National Water Summary 1984-Hydrologic events, selected water quality trends, and ground-water resources: U.S. Geological Survey Water-Supply Paper 2275, $467 \mathrm{p}$.

-----1986, National Water Summary, 1985-Hydrologic events and surface-water resources: U.S. Geological Survey Water-Supply Paper 2300, $506 \mathrm{p}$.

-----1988, National Water Summary, 1986-Hydrologic events and ground-water quality: U.S. Geological Survey Water-Supply Paper 2325, $560 \mathrm{p}$.

Vecchioli, John, 1965, Directional hydraulic behavior of a fractured-shale aquifer in New Jersey, in International Symposium on Hydrology of Fractured Rocks, Yugoslavia, 1965, Pro-ceedings, v. 1: International Association of Scientific Hydrology Publication 73, p. 318-326.

Vecchioli, John, Gill, H.E., and Lang, S.M., 1962, Hydrologic role of the Great Swamp and other marshland in upper Passaic River basin: American Water Works Association Journal, v. 54 , no. 6 , p. $695-701$.

Warman, J.C., and Causey, L.V., 1962, Geology and ground water resources of Calhoun County, Alabama: Geological Survey of Alabama County Report 7, 77 p. 
Warman, J.C., Causey, L.V., Burks, J.H., and Ziemand, H.W., 1960, Geology and groundwater resources of Calhoun County, Alabama, an interim report: Geological Survey of Alabama Information Series 17, 67 p.

Webster, D.A., 1976, A review of hydrologic and geologic conditions related to the radioactive solid-waste burial grounds at Oak Ridge National Laboratory, Tennessee: U.S. Geological Survey Open-File Report 76-727, 85 p.

Weigand, P.W., and Ragland, P.C., 1970, Geochemistry of Mesozoic dolerite dikes from eastern North America: Contributions to Mineralogy and Petrology, v. 29, p. 195-214.

Wood, C.R., 1980, Summary ground-water resources of Centre County, Pennsylvania: Pennsylvania Geological Survey, 4th Series, Water Resource Report W-48, 60 p.

Wood, C.R., Flippo, H.N., Jr., and Lescinsky, J.B., 1972, Water resources of Lehigh County, Pennsylvania: Pennsylvania Geological Survey, 4th Series, Water Resource Report W-31, $263 \mathrm{p}$.

Wood, C.R., and Wood, W.W., 1982, Water resources summary for Early Mesozoic basins, in U.S. Geological Survey Workshop on Early Mesozoic Basins of Eastern North America, Proceedings: p. 41-45.

Woodward, N.B., ed., 1985, Valley and Ridge thrust-belt-Balanced structural sections, Pennsylvania to Alabama: Appalachian Basin Industrial Associates, University of Tennessee Department of Geological Sciences, Studies in Geology 12, 64 p.

Wright, W.G., 1990, Ground-water hydrology and quality in the Valley and Ridge and Blue Ridge physiographic provinces of Clarke County, Virginia: U.S. Geological Survey WaterResources Investigations Report 90-4143, $61 \mathrm{p}$.

Zapecza, O.S., and Szabo, Zoltan, 1988, Natural radioactivity in ground water-A review, in U.S. Geological Survey, National Water Summary, 1986-Hydrologic events and groundwater quality: U.S. Geological Survey WaterSupply Paper 2535, p. 50-57.

Zurawski, Ann, 1978, Summary appraisals of the Nation's ground-water resources-Tennessee region: U.S. Geological Survey Professional Paper 813-L, $35 \mathrm{p}$. 